\title{
MARIA LAVAS, MASCONS, LAYERED COMPLEXES, ACHONDRITES AND THE LUNAR MANTLE
}

\author{
G. M. BIGGAR, M. J. O'HARA and D. J. HUMPHRIES \\ Grant Institute of Geology, University of Edinburgh, Scotland \\ and
}

A. PECKETT

Department of Geology, University of Durham, England

\begin{abstract}
Experimental data show Apollo 11 and 12 lava compositions to be controlled by fractional crystallization close to the lunar surface, in a process which yields achondrite-like igneous rocks as underlying complementary crystal accumulates. Volatilization losses during eruption can account for most other chemical differences between lunar lavas and common terrestrial magmas. No specific hypotheses of the composition, mineralogy, or origin of lunar interior can be sustained until the extent of these processes is known. A terrestrial upper-mantle-type lunar interior cannot yet be excluded. The assumption that maria surface lavas are primary partial melts is unjustified and leads to a postulated lunar interior with too low $\mathrm{Mg} / \mathrm{Mg}+\mathrm{Fe}$ to serve as a source for Apollo 14 and other igneous liquids. Other workers' uncontrolled visual estimates of crystallinity in experimental charges, purporting to show that maria lavas were not modified by low pressure fractionation, are irreconcilable with the chemistry of the residual liquids developed in our 'reversed' equilibrium experiments. The undesirability of using glass as a starting material for this type of experiment is re-emphasized.
\end{abstract}

\section{Introduction and Statement}

The preferred interpretation (Biggar et al., 1971) of available lunar samples involves at least the following sequence of events:

(1) Lunar accretion.

(2) Primordial differentiation to yield crust by partial melting of interior.

(3) Continued but rapidly declining rate of meteoritic impacts, including formation of maria basins.

(4) Triggered release of further partial melts from the interior to fill maria basins with lakes of lava. (see 8)

(5) Slow consolidation of the lava lakes with strong fractional crystallization in each liquid body. (see 12)

(6) Random or intermittent eruption of underlying residual differentiated liquid through the crusts of the lava lakes to form the surface lavas sampled by Apollo 11 and 12 missions.

The age of these events is $\sim 4.5$ b.y. Apparent younger $\mathrm{Rb} / \mathrm{Sr}$ isochron ages date one or more metamorphic events. *

Significant facets of this interpretation are that:

(7) There is no evidence that the lunar interior, or the primary partial melts derived from it, differ significantly in composition from those present in the outer parts of the Earth: there is some evidence that the two groups of materials are similar.

(8) Fire fountaining during initial lava eruption (see 4) led to small droplet forma-

* See footnote, p. 137. 
tion and selective volatilization of elements, as well as fall in oxygen fugacity to the point where metallic iron began to separate. Two of the four major chemical peculiarities of maria lavas (great depletion in all the volatile elements, and most siderophile elements) result directly from the loss of vapour phase at stage (4) coupled with the settling out of a layer of metal phase at the floor of the lava lake after fire fountain droplets had fallen back into the lake.

(9) The extent of metal phase production determines the mass concentration effects.

(10) Prolonged fractional crystallization, just as in large terrestrial lava bodies, greatly reduced the residual liquid volume while concentrating the remaining $\mathrm{FeO}$, the $\mathrm{TiO}_{2}$, and rare-Earth elements (REE) in that reduced volume, thus producing the third chemical peculiarity of maria surface lavas.

(11) Volatilization losses of $\mathrm{Na}_{2} \mathrm{O}$ (in particular) at stage (4) caused excessive precipitation of calcium-poor pyroxenes accompanied by very calcic plagioclase from the differentiating lava lake. Prolonged plagioclase extraction aided by volatilization produced the fourth chemical peculiarity, the marked europium deficiency in the late residual liquids, which occasionally spilled out over the crust as lava flows.

(12) The petrographic character of the crystal accumulates in the underlying maria structure is such that fragments of them observed to fall upon the Earth would be classified as achondrites, irons or stony irons. The essence of the interpretation is conveyed in Figure 1.

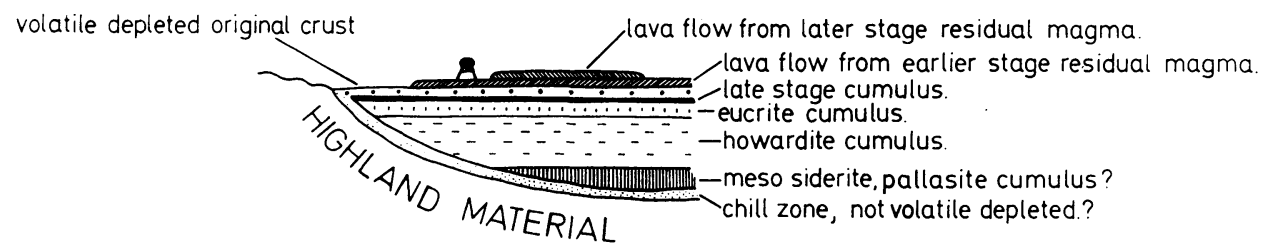

Fig. 1. Hypothetical cross section of lunar maria illustrating disposition of rock types consistent with experimental and petrological observations, topography, and Duke and Silver's (1967) interpretation of the achondrites (reproduced from Biggar et al., 1971, Figure 10). Because both the chill zone and the first crust on the lake are formed from magma which may have fire-fountained on eruption, they will have suffered some volatilization losses, and iron precipitation, but not fractional crystallization. Impact melted glasses of howardite/eucrite-like composition are reported from soils at some sites (Marvin et al., 1972).

This paper summarises the arguments demonstrating (i) that the maria are fractionated lava lakes, and not piles of successive individual flows. (ii) That their surface lavas represent strongly fractionated residual liquids from those lakes. (iii) That selective volatilization was a significant event. (iv) That the true age of the major igneous events is $4.5 \mathrm{~b} . \mathrm{y}$. ${ }^{*}$ and $(\mathrm{v})$ that the $\mathrm{Mg} / \mathrm{Fe}+\mathrm{Mg}$ of the lunar interior closely resembles that of the Earth's upper mantle.

The obscuring effect of the near-surface events which modify lunar rock compositions make it difficult to place any valid constraints on the nature of the lunar interior, beyond those already imposed by inference from astronomical observations. Firm

* See footnote p. 137. 
choice between early fission, capture and conjugate birth as the origin of the Moon is impossible, as yet, on the strength of petrological or chemical data.

The interpretation presented above is founded upon certain observations of phase equilibria produced in our laboratory. Much of this paper is concerned with establishing the accuracy, sufficiency and relevance of these data. Experimental data from another laboratory have been alleged to invalidate our conclusions; some attention is given below to identifying serious discrepancies both within, and between those data and our own results, and to understanding the reasons for the discrepancies.

\section{Maria Surface Lavas Are not Primary Partial Melts of Lunar Interior; Lunar Maria Are Sites of Extreme Fractional Crystallization}

Strom (1971 and pers. comm.) reports stratigraphic sequences of very extensive thin flows emanating from wrinkle ridges in Mare Imbrium. The older lava flows are 'red', and the upper later flows are 'blue', indicating increase in $\mathrm{TiO}_{2}$. Final effusions from the fractures appear to be small volumes of very viscous light coloured lava. The telescopic evidence for differentiation increasing with passage of time in a mare surface eruption sequence is strong.

Large lakes or chambers of magma undergo extreme differentiation by fractional crystallization during their solidification (Wager and Brown, 1968). At a late stage a very small fraction of the original liquid volume becomes grossly enriched in those rare elements selectively rejected by the crystals forming and sinking to the floor of the body to form cumulates. Periodic escape of such residual liquids onto the surface (due to foundering or impact fracturing of the lava-lake crust) will then give chemical sequences inverted with respect to those expected in a direct partial melting sequence, the latest lava flows being the most enriched in rare elements.

The elements which are selectively rejected by crystalline or immiscible liquid, phases separating at an early stage from basaltic magmas and which might, therefore, be expected to become enriched in the residual liquids developed during consolidation of the lava-lakes, may be subdivided as follows:

(i) Volatile e.g. $\mathrm{H}_{2}, \mathrm{O}_{2}, \mathrm{H}_{2} \mathrm{O}, \mathrm{CO}_{2}, \mathrm{~F}, \mathrm{Cl}, \mathrm{Br}, \mathrm{I}, \mathrm{S}, \mathrm{Se}, \mathrm{Na}, \mathrm{K}, \mathrm{Rb}, \mathrm{Cs}, \mathrm{Zn}, \mathrm{Cd}, \mathrm{Hg}, \mathrm{B}$, In, $\mathrm{Tl}, \mathrm{N}, \mathrm{P}, \mathrm{As}, \mathrm{Sb}, \mathrm{Te}, \mathrm{Bi}, \mathrm{Pb}$. These, however, will not reach high concentrations in residual liquids if a gaseous phase has separated at low pressure.

(ii) Chalcophile These include some of the volatile group, and will not reach high concentrations in residual liquids if a sulphide phase (crystal or liquid) has separated.

(iii) Siderophile e.g. $\mathrm{Co}, \mathrm{Ni}, \mathrm{Pd}, \mathrm{Pt}, \mathrm{Os}, \mathrm{Rh}, \mathrm{Ag}, \mathrm{Au}$. These will not reach high concentrations in residual liquids if oxygen fugacity has been low enough to cause the separation of an iron-rich metal phase.

(iv) Lithophile Any Fe remaining oxidised in the liquid after filling of the lava-lake will thereafter be strongly concentrated by fractional crystallization into the residual liquids together with $\mathrm{Li}, \mathrm{Sr}, \mathrm{U}, \mathrm{Th}, \mathrm{Ce}, \mathrm{Nb}, \mathrm{Ba}, \mathrm{Y}, \mathrm{R} . \mathrm{E} . \mathrm{E} ., \mathrm{Ti}, \mathrm{Zr}, \mathrm{V}, \mathrm{Cr}$. These will be progressively concentrated in the residual liquids regardless of volatilization, sulphide or metal phase precipitation, subject to the following provisos: 
(a) $\mathrm{Fe}, \mathrm{Cr}$ and $\mathrm{V}$ will remain high or be progressively concentrated provided there has not been precipitation of spinel (chromite, magnetite) or abundant Ca-rich pyroxene (diopside, augite).

(b) The light and heavy REE elements will be comparably concentrated provided that large amounts of Ca-rich pyroxene have not precipitated.

(c) Europium will not be concentrated if abundant plagioclase feldspar has precipitated, and may have been selectively volatilized.

The chemistry of maria surface lavas is marked by high concentration of $\mathrm{Fe}, \mathrm{Ba}, \mathrm{Y}$, $\mathrm{REE}, \mathrm{Ti}, \mathrm{Zr}, \mathrm{V}, \mathrm{Cr}$, without marked relative fractionation of the REE, but with a spectacular relative depletion of Eu. Extreme fractional crystallization and separation of calcic plagioclase and calcium-poor pyroxene, with little spinel or Ca-rich pyroxene is indicated.

In maria lavas great depletion of siderophile elements indicates extraction of a metal phase. Allowing for the initial Fe depletion caused by this, the present $\mathrm{Fe} / \mathrm{Mg}$ ratio and high concentrations of $\mathrm{REE}, \mathrm{Ti}, \mathrm{Zr}$, are such as might be generated in the final $1-2 \%$ of liquid in a consolidating lava lake.

The fractionated lava lake hypothesis predicts that the very high concentrations of elements such as $\mathrm{Ti}$ will be found in less than $2 \%$ of the total mass of the maria, and that these concentrations will increase in the surface lava flows from any one lava lake as they become younger, consistent with Strom et al.'s observation of increasing 'blueness' with passage of time, at least until a late stage when Ti-rich mineral begins to crystallize. Essene et al.'s (1970) hypothesis of successive flows of primary partial melts, each representing a very small fraction (less than $1 \%$ ) of the source lunar mantle requires on the contrary (i) that concentrations of titanium should decrease, rather than increase with passage of time, and (ii) that huge volumes of the Moon's interior should have been 'worked over' and depleted of a minute fraction of partial melt, the mechanics of whose flow and collection into a few lava reservoirs presents severe problems. The mass balance problem is a principal objection to the successive lava flow hypothesis - it does not arise in the fractionated lava lake hypothesis because only $1-2 \%$ as much lunar mantle needs to be processed to yield the observed element concentrations in the last extreme differentiate of the lava lake.

One of the very minor but characteristic late stage rocks produced by extreme crystal fractionation in large terrestrial lava bodies is a hedenbergite-granophyre (Wager and Brown, 1968). Mason et al. (1971) now report a fragment of hedenbergitegranophyre from regolith at the Apollo 12 site.

\section{Lunar interior; High $\mathrm{Mg} / \mathrm{Mg}+\mathrm{Fe}$}

Phase equilibria data from Apollo 11 samples did not exclude the possibility of a lunar mantle of terrestrial upper mantle composition (O'Hara et al., 1970). Figure 2 summarises available relevant information on the partition of $\mathrm{Mg}$ and $\mathrm{Fe}$ between coexisting olivines and liquids, and the inferences which may be drawn from them about the $\mathrm{Mg} / \mathrm{Mg}+\mathrm{Fe}$ of the source regions of the liquids. The solid curve represents 


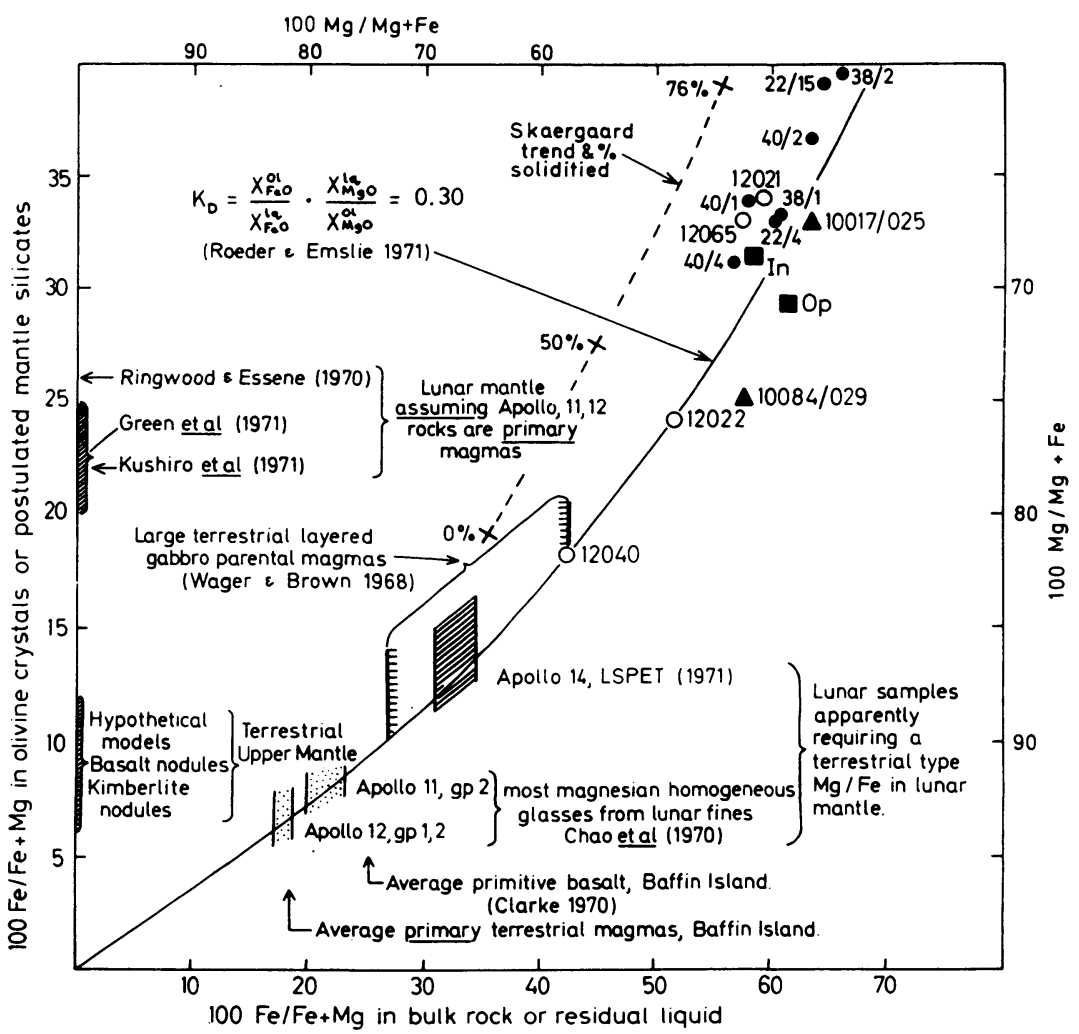

Fig. 2. $\mathrm{Fe} / \mathrm{Mg}$ distribution between olivine crystals, or postulated lunar mantle and liquid, for Apollo 11, 12 and 14 samples; small filled circles and triangles from experimental data of Biggar et al. (1971); open circles from liquidus data of Green et al. (1971), filled squares from petrographic observation (James and Jackson, 1970) of the first olivines in the Apollo 11 intersertal

$(\mathrm{In})$ and ophitic $(\mathrm{Op})$ group lavas.

an empirical partition function found to fit most terrestrial data. It is seen to fit data from quenching experiments on Apollo 11 samples (Biggar et al., 1971, triangles), Apollo 12 samples (Biggar et al., 1971, filled circles), liquidus olivine compositions quoted for four rocks (Green et al., 1971, open circles) and phenocryst core compositions (James and Jackson, 1970 filled squares) in two groups (Op, ophitic; In, intersertal) of Apollo 11 lavas, plotted against average compositions of these groups (Compston et al., 1970).

On the assumptions that Apollo 11 and Apollo 12 lavas represented primary partial melts, Ringwood (1970) and three other groups of workers have deduced relatively low $\mathrm{Mg} / \mathrm{Mg}+\mathrm{Fe}(0.75-0.80)$ in the silicates of the lunar mantle, as noted on the left side of the figure.

However, Apollo 14 samples have much higher $\mathrm{Mg} / \mathrm{Mg}+\mathrm{Fe}$ than the maria surface lavas, implying equilibration against silicates with $\mathrm{Mg} / \mathrm{Mg}+\mathrm{Fe} \sim 0.87$. These lavas cannot be interpreted as more advanced partial melts of some more iron-rich mantle 
because they have higher concentrations, than do lavas collected from maria-surfaces, of some incompatible elements which partition almost wholly into whatever volume of liquid is available. Nor can they be interpreted as partial melts depleted in metallic iron because relative to lavas collected from maria surfaces, they are richer in nickel, which dissolves preferentially in, and would be eliminated with a metal phase. These Apollo 14 liquids are clearly more primitive in $\mathrm{Mg} / \mathrm{Mg}+\mathrm{Fe}$ than those erupted at the Apollo 11 and 12 sites, which are presumably derived by fractional crystallization from some primitive parent. Brown et al. (1971) and Brown (pers. comm. 1971) report olivines with $\mathrm{Mg} / \mathrm{Mg}+\mathrm{Fe} \sim 0.88-0.90$ and comment on their implications for the lunar mantle. It may transpire that Apollo 14 magmas have the characteristics of primary magmas developed on a large scale during the initial differentiation and crust formation of the Moon (LSPET 1971) in a period when incompatible element concentrations and $\mathrm{Fe} / \mathrm{Mg}$ ratio were sharply reduced in the lunar mantle. Still more magnesian basic glasses are reported by Chao et al. (1970) from the lunar fines, requiring a source region whose silicates have $\mathrm{Mg} / \mathrm{Mg}+\mathrm{Fe} \sim 0.91-0.94$ similar to that demanded by the most primitive terrestrial partial melts (Clarke 1970) and evidenced in the ultramafic nodules blasted to the Earth's surface in kimberlite eruptions.

\section{Lunar Maria, Layered Intrusions, Mascons}

The distinctive feature of terrestrial layered intrusions is the decrease of $\mathrm{Mg} / \mathrm{Mg}+\mathrm{Fe}$ in the residual liquids resulting from prolonged fractional crystallization. The dashed line (Figure 2) links points for cumulus olivine and coexisting liquid deduced for the successive residual liquids of the Skaergaard intrusion at various percentages of solidification of the original parental liquid (from Wager and Brown, 1968, Figure 119).

O' Hara et al. (1970) and Biggar et al. (1971) have proposed that solidification of the lunar maria lava lakes proceeds in a manner analogous to that seen in large terrestrial layered intrusions, with the modification that early precipitation of metallic iron has depleted siderophile elements and inhibited equivalent decrease of $\mathrm{Mg} / \mathrm{Mg}+\mathrm{Fe}$ in the liquid until larger percentages of the parental liquid have solidified. Early precipitation of c. $3.7 \%$ of the initial magma as metallic iron would inhibit the evolution of a Skaergaard-type trend so that more than $90 \%$ crystallization would be necessary for the liquid to reach the $\mathrm{Mg} / \mathrm{Mg}+\mathrm{Fe}$ ratios of lunar maria surface lavas.

The extent of metallic iron precipitation, and the resulting excess mass in the early stages of maria filling will vary with volatilization losses and hence with the mechanics of the first eruption process, and will, therefore, vary from one mare to another. This is only one of many possible internal explanations of mascons (O'Hara et al., 1971), but the one which is supported by the experimental and petrological data (Biggar et al., 1971).

If circumstances were such that a constant hydrostatic head and constant volume of liquid were maintained in the maria basins (possible if the level of the surface is maintained by a 'water-table' effect reflecting widespread partial melting at some depth) the process of densification of the erupted magma by loss of $\mathrm{O}_{2}, \mathrm{Na}_{2} \mathrm{O}$ and $\mathrm{K}_{2} \mathrm{O}$ with 
accompanying precipitation of metallic iron might lead to c. $5 \%$ extra mass being consolidated in the basin. An excess mass $\sim 10^{5} \mathrm{~g} \mathrm{~cm}^{-2}$, is required beneath the maria to yield observed mascon effects, equivalent to an extra $6 \%$ mass present in what would otherwise have been a gabbro column c. $6 \mathrm{~km}$ deep (well within the depth range possible in the lunar maria, and evident in terrestrial layered bodies e.g. Stillwater complex $5.2 \mathrm{~km}$; Bushveld complex $7.3 \mathrm{~km}$, with lateral extent of $300 \times 400 \mathrm{~km}$ ). Thus far, therefore, we find no constraints which exclude the possibility of a lunar interior and derived liquids comparable with those present in the Earth's upper mantle, and some evidence which points to considerable similarities.

All other factors being equal, the above hypothesis predicts that surface lavas from maria with larger mascons should exhibit higher non-volatile incompatible element concentrations at the same $\mathrm{Fe} / \mathrm{Mg}$ ratio. The information required to test this prediction will take time to accumulate. It also predicts that lunar volcanic rocks will show some positive correlation between higher alkali retention and lesser depletion of siderophile elements (e.g. $\mathrm{Ni}$ ) - this is true of Apollo 14 igneous rocks compared with Apollo 11 and 12 materials.

\section{Selective Volatilization from Lunar Lavas}

The rate of mass loss of $\mathrm{Na}_{2} \mathrm{O}$ from a basic magma which is necessary to extract $1 \% \mathrm{Na}_{2} \mathrm{O}$ by weight from the liquid is readily calculated.

During fire fountaining, droplet surfaces will not be rapidly cooled because they are surrounded by other equally hot droplets. Assuming an ejection velocity of $\sim 10^{4} \mathrm{~cm} \mathrm{~s}^{-1}$, flight time $\sim 10^{2} \mathrm{~s}$ and a droplet size of $\sim 10^{-2} \mathrm{~cm}$, a loss rate of $\sim 2.5 \times 10^{-6} \mathrm{~g} \mathrm{~cm}^{-2} \mathrm{~s}^{-1}$ at $1500 \mathrm{~K}$ would suffice. Loss rates of $10^{-4}$ to $10^{-5} \mathrm{~g} \mathrm{~cm}^{-2}$ $\mathrm{s}^{-1}$ are required for similar losses from thin sheets of liquid flowing up to a hundred kms across the lunar surface, or fire fountain droplets averaging up to $1 \mathrm{~cm}$ in size.

Experiments on a terrestrial iron-rich tholeiite magma near its liquidus temperature are summarised in Table I. The mass loss rate of $\mathrm{Na}_{2} \mathrm{O}$ is $>10^{-5} \mathrm{~g} \mathrm{~cm}^{-2} \mathrm{~s}^{-1}$ at $\sim 1450 \mathrm{~K}$ and $\mathrm{fO}_{2} \sim 10^{-11}$ to $10^{-15}$ bar and is appreciably higher than reported by $\mathrm{O}^{\prime}$ Hara et al. (1970) when $\mathrm{fO}_{2} \sim 10^{-8}$ to $10^{-9}$ bar. This directly measured loss rate is similar to those inferred by application of the Langmuir equation (rate $=P_{v} \sqrt{ }(\mathrm{mol} w t)$ $/ 2 \pi R T)$, vaporization coefficient of 1) to De Maria et al.'s (1971) vapour pressures, or by assuming a rate $\sim 10^{2}$ times greater than for pure $\mathrm{SiO}_{2}$ or bulk tektite compositions (Chapman and Scheiber 1969). The lower loss rates for $\mathrm{K}$ than Na presumably reflect the lower activity of potassium in the melt.

Selective loss of $\mathrm{Na}_{2} \mathrm{O}$ at least must have occurred during eruption of lunar lavas, and the gross depletion of these rocks in all volatile elements points to the general nature of this conclusion.

Restoration of alkalis and other volatiles including oxygen to the lunar lava compositions leads, among many other possible parents, to compositions familiar among terrestrial basalts. It is unsafe to assume that the present lava compositions are those 
TABLE IA

Volatilization study on Scourie iron-rich tholeiite dike; $\mathrm{fO}_{2} \sim 10^{-12}$ bar

\begin{tabular}{|c|c|c|c|c|c|c|}
\hline & $\begin{array}{l}\text { Time } \\
\mathrm{h}\end{array}$ & $\begin{array}{l}\text { Temp } \\
{ }^{\circ} \mathrm{C}\end{array}$ & $\begin{array}{l}\text { Pressure } \\
\text { (torr) }\end{array}$ & Comments & $\begin{array}{l}\mathrm{Na}_{2} \mathrm{O} \\
\text { wt } \%\end{array}$ & $\begin{array}{l}\mathrm{K}_{2} \mathrm{O} \\
\text { wt } \%\end{array}$ \\
\hline Start & - & - & - & & $2.38+a$ & $0.92+{ }^{a}$ \\
\hline V. 63 & 1 & $1150-60$ & $10^{-4}$ & $\left\{\begin{array}{l}\text { part devitrified } \\
\text { bubbled surface, black glass powder }\end{array}\right.$ & 1.93 & 0.88 \\
\hline V. 62 & 5 & 1160 & $10^{-4}$ & part devitrified & 1.51 & 0.97 \\
\hline V. 64 & 24 & 1160 & $1.5 \times 10^{-4}$ & $\left\{\begin{array}{l}\text { trace devitrification } \\
\text { smooth surface, brown glass powder }\end{array}\right.$ & 0.60 & 0.91 \\
\hline V. 57 & 60 & 1175 & $2 \times 10^{-5}$ & $\left\{\begin{array}{l}\text { trace devitrification } \\
\text { smooth surface, brown glass powder }\end{array}\right.$ & 0.16 & 0.25 \\
\hline V. 58 & 240 & 1175 & $2 \times 10^{-5}$ & $\left\{\begin{array}{l}\text { trace devitrification } \\
\text { smooth surface, brown glass powder }\end{array}\right.$ & 0.13 & 0.12 \\
\hline V. 59 & 430 & 1175 & $\sim 5 \times 10^{-5}$ & $\left\{\begin{array}{l}\text { trace devitrification } \\
\text { smooth surface, brown glass powder }\end{array}\right.$ & 0.20 & 0.21 \\
\hline
\end{tabular}

a Not adjusted for $\mathrm{H}_{2} \mathrm{O}, \mathrm{Fe}_{2} \mathrm{O}_{3}$ in rock sample. Alkalis determined by flame photometer. Surface area of sample exposed $\sim 2.9 \mathrm{~cm}^{2}$

TABLE IB

\begin{tabular}{lrccr} 
& \multicolumn{1}{l}{ I } & \multicolumn{1}{c}{ II } & \multicolumn{1}{l}{ III } & \multicolumn{1}{c}{ IV } \\
\hline $\mathrm{SiO}_{2}$ & 50.49 & 51.29 & 53.43 & 52.19 \\
$\mathrm{TiO}_{2}$ & 2.87 & 2.81 & 2.82 & 2.97 \\
$\mathrm{Al}_{2} \mathrm{O}_{3}$ & 12.48 & 12.44 & 12.96 & 12.91 \\
$\mathrm{FeO}$ & 16.57 & 16.28 & 16.03 & 17.13 \\
$\mathrm{MnO}$ & 0.26 & $(0.26)$ & $(0.26)$ & 0.27 \\
$\mathrm{MgO}$ & 4.85 & 4.84 & 4.92 & 5.02 \\
$\mathrm{CaO}$ & 8.89 & 8.97 & 9.24 & 9.19 \\
$\mathrm{Na} 2$ & 2.41 & 2.13 & 0.09 & 0.09 \\
$\mathrm{~K}_{2} \mathrm{O}$ & 0.93 & 0.98 & 0.25 & 0.25 \\
$\mathrm{P}_{2} \mathrm{O}_{5}$ & 0.25 & - & - & - \\
\hline & 100.00 & 100.00 & 100.00 & 100.02 \\
\hline
\end{tabular}

I - Scourie dike, 10727 from thin vein at Geodh Eanruig (O'Hara, 1961; Table III, locality II, p. 856, plate XVIII), recalculated less $\mathrm{H}_{2} \mathrm{O}$ and with all iron as $\mathrm{FeO}$, from complete wet method analysis by M. R. Saunders.

II - Same material after $2 \mathrm{~h}$ at $1200^{\circ} \mathrm{C}$ in molybdenum capsule at $\mathrm{pO}_{2} \sim 10^{-12.0}$ bar, recalculated to $100 \%$ less $\mathrm{P}_{2} \mathrm{O}_{5}$ from microprobe analyses of glass fragments.

III - Same material as I after $60 \mathrm{~h}$ at $1175^{\circ} \mathrm{C}$ in molybdenum crucible at low $\mathrm{pO}_{2}$ and total pressure of $2 \times 10^{-5}$ torr. Electron microprobe analysis.

IV - Analysis I recalculated less $\mathrm{P}_{2} \mathrm{O}_{5}$ and appropriate alkalis to compare with III.

Note: alkali loss apparent between I and II; apparent loss of FeO from glass III (? reduced and reacted with crucible) and pick-up of $\mathrm{SiO}_{2}$ (? from cracking of silicones oil of diffusion pump). 
of the pre-eruption liquids, let alone the primary partial melts, and premature to ascribe their volatile-poor characteristics to the Moon as a whole on the strength of that assumption.

The feldspar phenocrysts in samples 14073, and 14310 record pre-eruption levels of $\mathrm{Na}_{2} \mathrm{O}$ and $\mathrm{K}_{2} \mathrm{O}$ in the liquids at least 2-3 times higher than the levels on final consolidation of these lavas (Brown and Peckett, 1971). Restoration of the missing alkalis and c. $0.25 \% \mathrm{O}_{2}$ to the present composition of 14310 leads to a composition quite familiar among inter alia the Kamchatka calcalkaline volcanics.

Volatilization which would have accompanied eruption and which selectively separates $\mathrm{Rb}$ from $\mathrm{Sr}$, would have destroyed the orderly $4.5 \mathrm{~b}$.y. model ages and the 4.5 b.y. isochron defined by the different bulk rock samples collected at the Apollo 11 (ophitic group) and Apollo 12 sites. Therefore, no igneous event can have affected these rocks since 4.5 b.y. (compare Urey et al., 1971) and the internal mineral isochrons from individual rocks may date devitrification or other metamorphic events. 3.3-3.7 b.y. ago. (Liquids low in volatiles, alkalies and $\mathrm{Fe}^{3+}$ such as were produced in the experiments of Table I, were very slow to nucleate and some did not devitrify even in cooling times of $1 \mathrm{~h}$ from $1175^{\circ} \mathrm{C}$ to $700^{\circ} \mathrm{C}$.) *

\section{Accuracy Precision and Significance of the Experimental Data}

Experiments performed on lunar samples and related compositions define, at various pressures, the (liquidus) crystalline phases stable with a liquid of the sample composition. This information can then be used to deduce the crystalline species present in the solid material with which the liquid last equilibrated provided that the pressure of that last equilibration is indicated by other information, or can be reliably estimated.

If that pressure is assumed, provisional conclusions only can be reached (O'Hara et al., 1970); but addition of $10 \%$ of what you fancy to produce a more convenient liquidus phase is less than objective.

We have presented experimental evidence that maria surface lava compositions have low pressure cotectic character, controlled by crystal-liquid equilibria at low pressure, leading to the preceding interpretation of maria structure and origin. Others claim there is no evidence of significant low pressure control; go further in claiming that there has been no control of particular lunar lava compositions at any pressure other than that of genesis by partial melting of the lunar mantle; and assume the depth of that partial melting process. From this basis they deduce a model of a volatile depleted, strongly reduced pyroxenite or olivine-pyroxenite lunar interior. If our experimental observations are correct, maria surface lavas are not primary magmas and the model developed by Ringwood and Essene (1970), Ringwood (1970) and Green et al. (1971) is a chimera.

The controversy centres on the accuracy of our observation of close approach to cotectic character at low pressure, which has been criticized by Ringwood (1970) and

* Wasserburg and Papanastassiou (1971) suggest crustal or soil contamination of the lavas, vitiating this argument and most petrogenetic discussion based on minor element chemistry. 
Green et al. (1971), on the strength of their visual estimates of crystallinity, in their products obtained from starting material long deprecated for its propensity to yield metastable products. Moreover, much information necessary for the evaluation of their statements was not presented by Green et al. (1971). The temperatures and durations of individual experiments were not given, nor is it clear which experiments used natural and which used synthetic materials (p. 602*). Without these data, claims to have produced the same result by different techniques are insubstantial. Details of the containers, atmospheres, temperatures and durations used in the initial glass preparations are needed to define the nature of the starting material. No calibration of the temperature or oxygen fugacity actually achieved in the charges was reported, and the pressure of some experiments is apparently unspecified (p. 610*). There were no data to establish the precision achieved in their visual estimates of percent crystallinity (Figure 2 caption*) which yield unrealistic residual liquid compositions.

There seem to be several inconsistencies in the data which were reported. For example, 12040 is given as showing plagioclase entry between 1120 and $1140^{\circ} \mathrm{C}$ (Figure $1^{*}$ ), near $1140^{\circ} \mathrm{C}$ (p. $603^{*}$ ), or between $1150^{\circ} \mathrm{C}$ and (presumably) $1140^{\circ} \mathrm{C}$ (p. $607^{*}$; but no $1150^{\circ} \mathrm{C}$ run is shown in their Figure 1). The percentage of crystals when plagioclase first appears in 12040 is reported variously as $70 \%$ (Figure $2 *$ ) or $50-60 \%$ (text on same page). There are no runs (Figure $1 *$ ) to substantiate the remark (p. $603 *$ ) that ilmenite enters at close to $1100^{\circ} \mathrm{C}$ in 12040 . The percentage of crystals at plagioclase entry in 12021 and 12065 are given as $40 \%$ and $45 \%$ (Figure $2 *$ ), but as $20-30 \%$, and $30-40 \%$, respectively, in the text (p. 607*). It was claimed (p. $611 *$ ) that 12021 could be derived by extraction of olivine, spinel and minor pigeonitic pyroxene from 12009 , yet the data (Figure $2 *$ ) indicate that a pyroxene olivine ratio of $3 / 1$ would be required in the extract from 12009 to yield a residuum with the phase behaviour of 12021 at temperatures of c. $1160^{\circ} \mathrm{C}$. Unlisted experiments of unknown bracket width and duration, which were apparently no more than syntheses from different starting materials as loaded, (see Figure 18, sequence 5 below) were presented (p. 608*) and claimed as reversals, and the reader is not told which compositions were used for these experiments.

Green et al. (1971) exploit small composition differences between experimental and natural minerals to stress the importance of 'direct supporting evidence from each sample'; but surely there is a prior need to place the experimental observations on a quantitative and objective basis.

Ringwood and Green (1972) have published a further criticism of our results which is disappointing for its misrepresentation of our statements, and for its reliance yet again on subjective visual estimates of crystallinity as a basis for criticism of our quantitative data. We have never stated that plagioclase was liquidus phase in natural Apollo 11 or 12 basalts ${ }^{* *}$, nor that the rocks were $o n$ the plagioclase-precipitating cotectic under the conditions encountered on the lunar surface, nor have we 'qualified' our original position that the lavas have compositions close to the 1 atmosphere cotectic (too close

* All page and figure references are to Green et al. (1971a).

** 10084 was a soil sample. 
for this to be a coincidence). Our position is adequately stated by Biggar et al. (1971), p. 634, para 2. We did not claim that other workers results were invalid because of the use of glass as a starting material; we have suggested that it may have had something to do with the discrepancies in observations between ourselves and Ringwood and Essene (1970) while clearly recognizing that the other two groups whom Ringwood and Green (1972) introduce into the argument worked on compositions substantially removed from those under discussion (Biggar et al., 1971, p. 631, para 2). The reader must judge for himself, in the light of the following remarks, however, how much of the actual disagreement stems from the choice of starting material, how much from inadequate calibration of techniques, and how much from uncertainties in more subjective observations. The loss of alkalis was not "claimed to cause an expansion of the primary fields of crystallization of mafic minerals": no variation in an intensive variable can change the extent of primary phase fields, and, therefore, of cotectic liquid compositions in a system of fixed composition. The effect of the loss of alkalis and oxygen is to shift the composition of the remaining condensed system towards ferromagnesian minerals as claimed by Biggar et al. (1971, p. 634) who showed (ibid, p. 635 , Equation (2)) a reaction in which the plagioclase declines from $64 \%$ to $55.5 \%$ consequent on alkali loss. The key question is whether the change in normative feldspar composition from $\mathrm{An}_{50}$ to $\mathrm{An}_{80}$, combined with the increase in pyroxene at the expense of olivine will offset the reduction in total plagioclase; and problems raised by possible reduction of iron oxides further complicate the issue.

The reader may want more proof that addition of alkalis suppresses rather than enhances the initial appearance of plagioclase than the difference between the two approximate visual estimates of $40-50 \%$ (at $1125 \pm 5^{\circ} \mathrm{C}$ ) and $35-50 \%$ (at $1115 \pm 5^{\circ} \mathrm{C}$ ) crystallinity at plagioclase entry with or without alkalis respectively, given by Ringwood and Green (1972, Table II; what the alkali addition does to the temperature of plagioclase or other phase entries is, of course, irrelevant). We cannot yet provide a definitive answer for the iron rich composition of maria basalts; for the more magnesian compositions of Apollo 14 samples addition of alkalis alone undoubtedly lowers the temperature of plagioclase appearance and (visual estimates!) moves the composition towards the cotectic liquid composition from the plagioclase liquidus field. Raising or lowering $\mathrm{fO}_{2}$ opposes this effect.

Contrary to Ringwood and Green's (1972) suggestion, nothing in any of the reported phase data, nor any conceivable data for effusive rocks could ever support the view that certain basalts were derived from regions below those at which plagioclase was a stable phase in the lunar interior. Such an interpretation depends upon totally different criteria. Their statement is only valid if 'residual' is inserted after 'stable' and the magmas are truly primary.

This disagreement is becoming long on immoderate wording and adrenalin, rather than on discussion of scientific data and techniques; we must, however, thank Ringwood and Green (1972) for pointing out our error in drawing of one of our figures from our data table. Biggar et al. $\left(1971\right.$, p. 633) carries an error $\left(9.1 \% \mathrm{TiO}_{2}\right)$ in the text. $9.2 \%$ is correct; in Table IV, column $1, \mathrm{Cr}_{2} \mathrm{O}_{3}=0.46 \%$, not $0.06 \%$. 


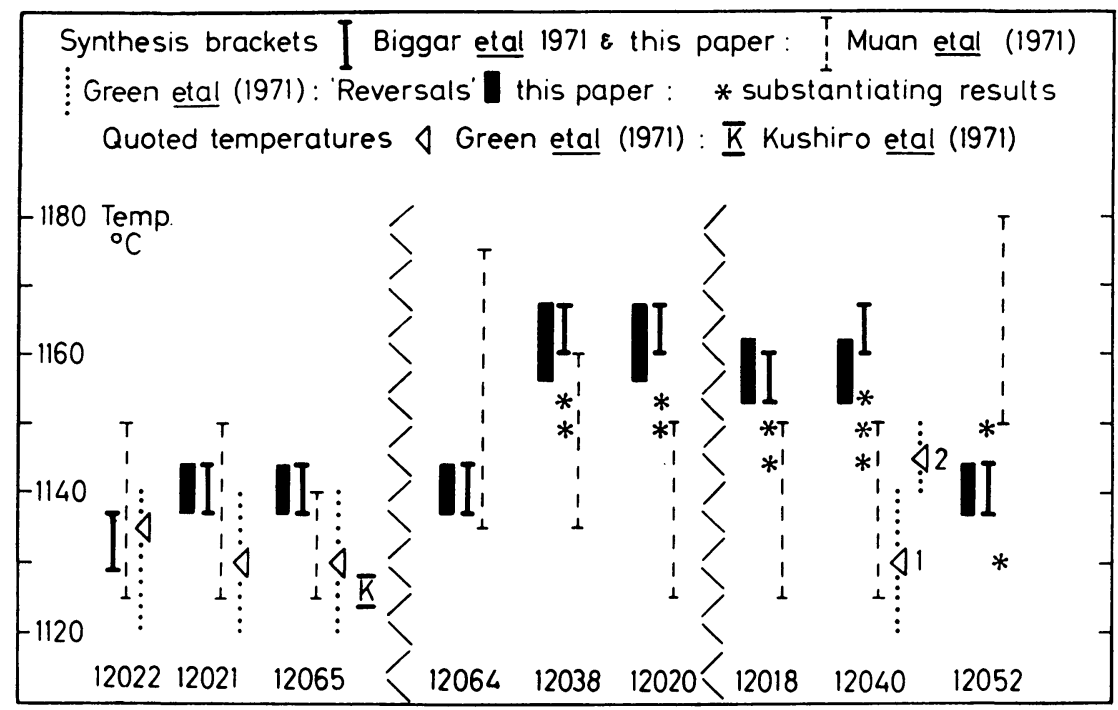

Fig. 3. Comparison of atmospheric pressure quenching data on the temperature of plagioclase appearance for 9 rocks reported on by four laboratories. Results substantiating one side of a bracket are shown where relevant by asterisks. Muan et al. (1971) finally reported plagioclase entry at $1125-1150^{\circ} \mathrm{C}$ in 12052 : Green et al. (1971b) now concede $\pm 5^{\circ}$ control precision and $\pm 10^{\circ} \mathrm{C}$ accuracy in their data. See Table IX, footnote (h).

TABLE II

Results of calculations of crystallinity contrasted with visual estimates ${ }^{\mathbf{a}}$

\begin{tabular}{|c|c|c|c|c|c|c|c|c|}
\hline $\begin{array}{l}100 \% \\
\text { rock }=\end{array}$ & $\%$ & residual liquid $+\%$ & $\mathrm{sp}$ & ol & pig & plag & $\begin{array}{l}\text { Estimated \% } \\
\text { crystals at } \\
\text { plagioclase entry }\end{array}$ & $\begin{array}{l}\% \text { crystals } \\
\text { visual estimates } \\
\text { Green } \text { et al. }(1971)\end{array}$ \\
\hline $12040^{\mathrm{b}}$ & 60 & cotectic glass 1160 & 1 & 29 & 9 & - & 40 & $\int 50$ to 60 (text) \\
\hline $12040^{b}$ & 54 & 12038 rock & 1 & 32 & 10 & 3 & 46 & 70 (Figure 2) \\
\hline $12052^{c}$ & 74 & $\left\{\begin{array}{l}12064 \text { cotectic glass } \\
\text { at } 1137^{\circ} \mathrm{C}\end{array}\right.$ & 1 & 3 & 17 & 6 & $<25$ & \\
\hline $12065^{c}$ & 77 & Plagioclase & 1 & 4 & 12 & 6 & $<20$ & $\sim(40$ (text) \\
\hline $12021^{\mathrm{c}}$ & 80 & already & $\operatorname{tr}$ & 1 & 14 & 5 & $<15$ & $\sim(45$ (Figure 2$)$ \\
\hline $12064^{c}$ & 88 & common & $\operatorname{tr}$ & 1 & 7 & 4 & $\sim 5$ & $\sim\left\{\begin{array}{l}40 \text { (Figure } 2 \text { ) } \\
\text {. }\end{array}\right.$ \\
\hline $12022^{\mathrm{c}}$ & 71 & cotectic glass $1129^{\circ} \mathrm{C}$ & 1 & 23 & 0 & 5 & $<25$ & $\sim 45$ (Figure 2$)$ \\
\hline
\end{tabular}

a These and subsequent calculations are advanced to show a major discrepancy between estimates of crystallinity by different methods. Quibbling over the choice of mineral compositions for the calculations could be endless, but would not lead to large changes in the final results.

b Calculation in Table III.

c These calculations used chrome spinel (Table IV, note 5), plagioclase $\left(\mathrm{An}_{85}\right)$, and pigeonite and olivine from 12038/2 (Biggar et al., 1971, Tables III, IV). 
MARIA LAVAS, MASCONS, LAYERED COMPLEXES, AND ACHONDRITES

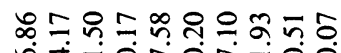

点 离离离

華

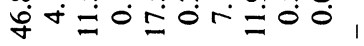

?ָ

苛

苞

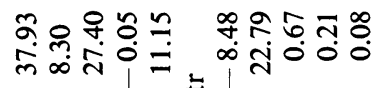

章

ลิ

这哥

总

证苋

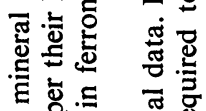

ญ్

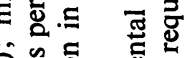

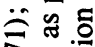

合记

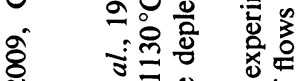

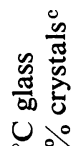

율

:

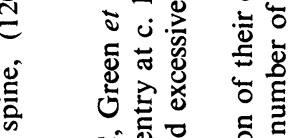

吾

ㅇํㅇ

U。

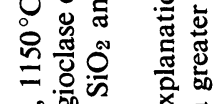

ล

三

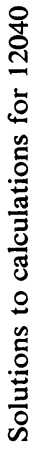

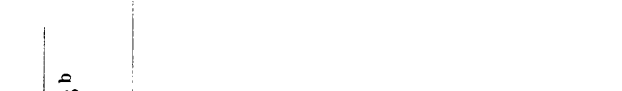

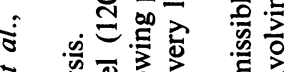

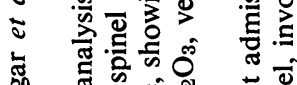

$+\infty$

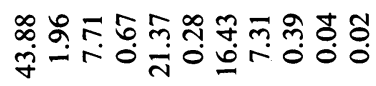

ปै

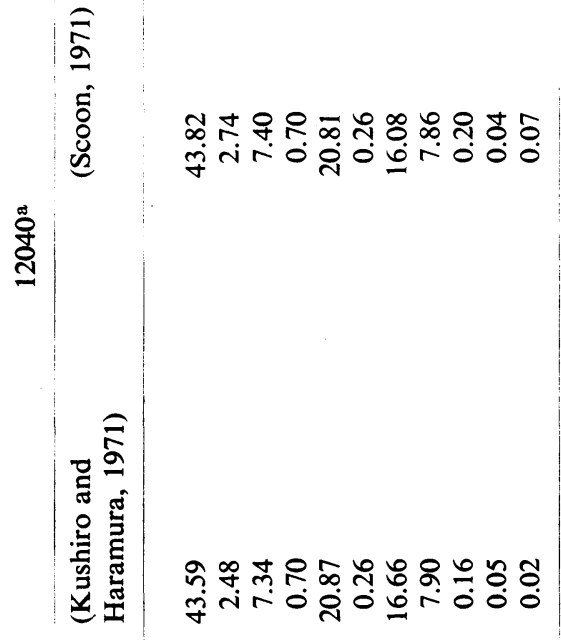

范。워

ठำ

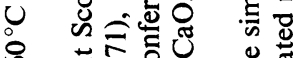

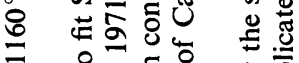

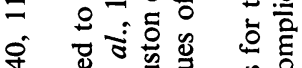

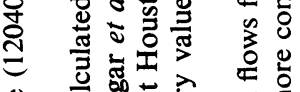

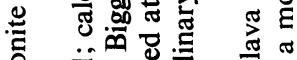

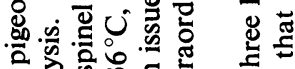

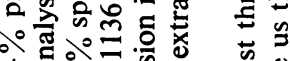

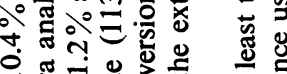

은

ชิ

8 要

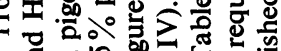

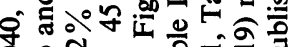

ชิ

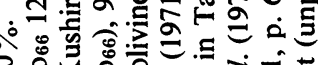

80

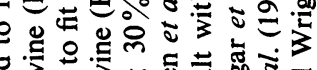

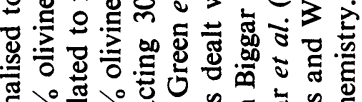

○๊ 
We emphasize that:

(1) The data of Biggar et al. (1971) establish significantly higher temperatures of plagioclase entry (Figure 3) than those claimed by Green et al. (1971). Muan et al. (1971), also using natural rock powder as starting material, could compromise with Biggar et al. (1971) on plagioclase entry at $1140-1160^{\circ} \mathrm{C}$ in most cases. Green et al. (1971) and Kushiro et al. (1971), both using glass as a starting material, would select a temperature in the $1120-1140^{\circ} \mathrm{C}$ range, but also agree with Muan et al. (1971).

(2) Calculations of percent crystallinity based on analyses of the coexisting phases in experimental products from Apollo 12 rocks (Tables II to IV) indicate much less crystallization at observed plagioclase entry (Figure 4) than claimed by Green et al. (1971) if levels of $\mathrm{MgO}, \mathrm{Al}_{2} \mathrm{O}_{3}, \mathrm{SiO}_{2}$ in the liquids are to be realistic.

(3) Products obtained from glass starting materials can be so fine grained (plate I) that percent crystallinity and crystalline-phase ratios are difficult to estimate, microprobe analysis of the residual glass is nearly impracticable, phases such as plagioclase are very difficult to detect in small amounts, and augite becomes difficult to distinguish optically from pigeonite.*

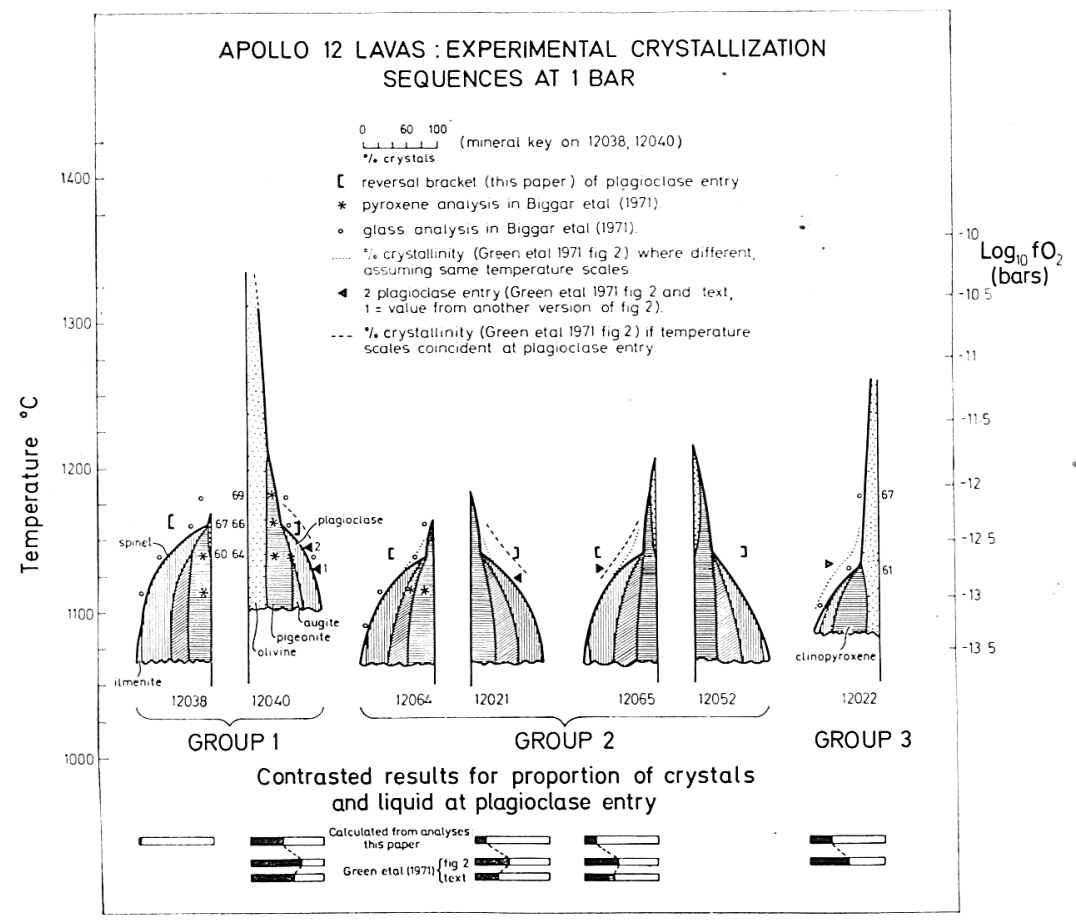

Fig. 4. Graphical representation of co-variation in $\mathrm{f0}_{2}$, temperature, phase assemblage and percentage crystallinity in Apollo 12 rock compositions (after Green et al., 1971, Figure 2, but with percent crystallinity based on calculations, and the calcium-rich and calcium-poor clino-pyroxenes distinguished except in 12022; note contrast between our calculated, and Green et al.'s estimated crystallinity at plagioclase entry, shown by proportional length of black bars).

* Green et al. (1971b) refer to this problem, but were confident they could distinguish pigeonite from inverted protohypersthene! 


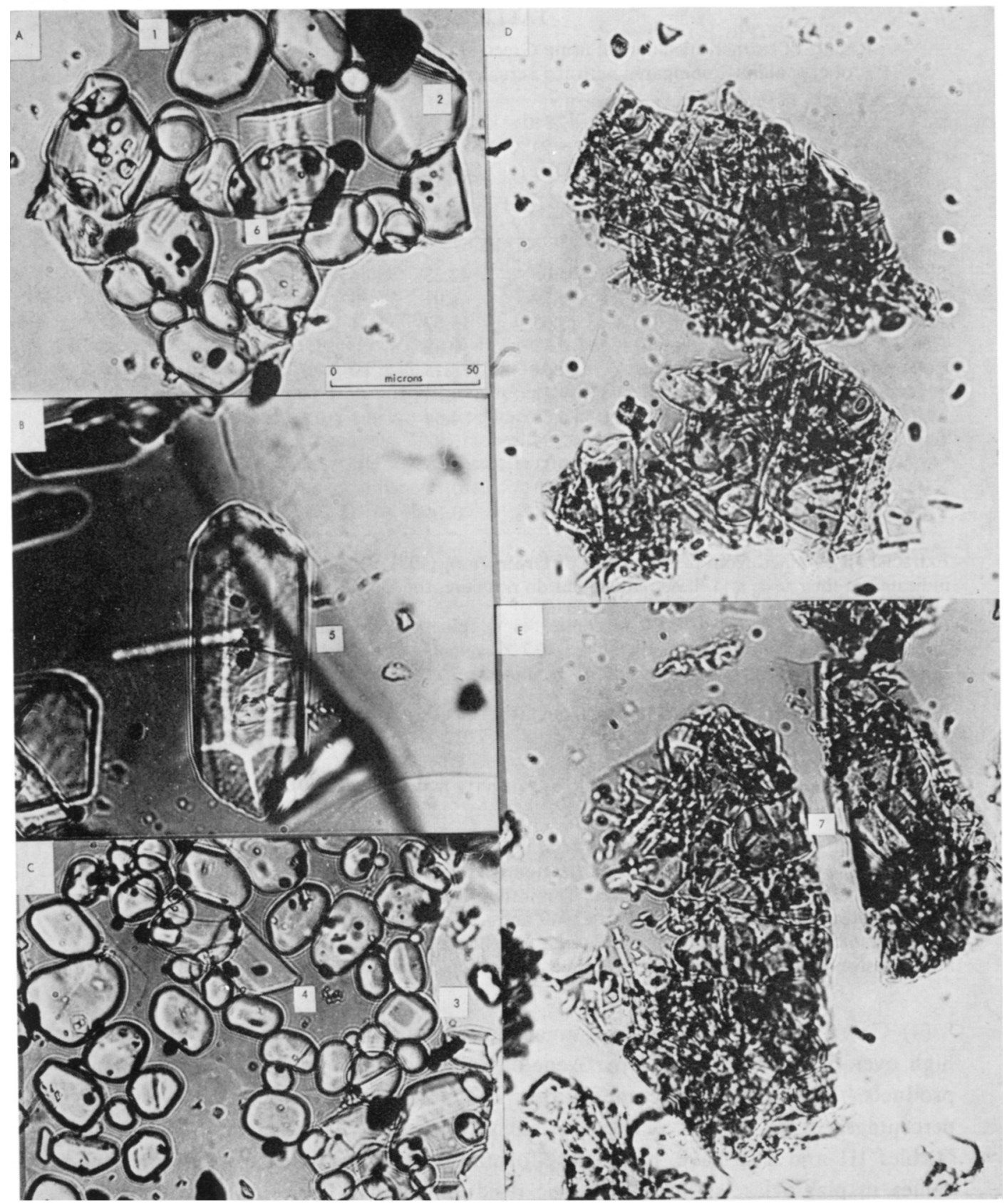

Plate I. Microphotographs (all same scale, see A) of products from reversal experiments on 12040 at $1162^{\circ} / 1153^{\circ} \mathrm{C} ; \mathrm{A}, \mathrm{B}, \mathrm{C}$ from rock powder starting material (experiment 035) showing euhedral olivines (1-3), pyroxene (4) and, again, with curving crack (5), plagioclase (6) and opaque spinel in glass. D, E from largely glass starting material (experiment 117) containing large olivines (7) as in $\mathrm{A}, \mathrm{C}$, but interlocking mesh of acicular pyroxenes whose minuscule width makes phase identification, estimation of crystallinity and microprobe analysis extremely difficult. 
TABLE IV

Results of extract calculations, using Green et al.'s (1971, Figure 2) visual estimates of crystallinity, compared with the actual analysed cotectic liquid compositions

\begin{tabular}{|c|c|c|c|c|c|c|c|c|}
\hline & $\begin{array}{l}12021 \\
-40 \% \\
\text { (A) }\end{array}$ & $\begin{array}{l}12065 \\
-45 \% \\
\text { (B) }\end{array}$ & $\begin{array}{l}12040 \\
-70 \% \\
\text { (C) }\end{array}$ & $\begin{array}{l}12040 \\
-50 \% \\
\text { (D) }\end{array}$ & $\begin{array}{l}12009 \\
-50 \% \\
\text { (E) }\end{array}$ & $\begin{array}{l}\text { Observed } \\
\text { real values } \\
12038,40,64 \\
\text { cotectic } \\
\text { liquids }\end{array}$ & $\begin{array}{l}12022 \\
-43 \% \\
\text { (F) }\end{array}$ & $\begin{array}{l}12022 / 15 \\
\text { observed } \\
1129^{\circ} \mathrm{C}\end{array}$ \\
\hline $\mathrm{SiO}_{2}$ & 43.16 & 41.77 & 37.68 & 41.06 & 42.33 & $46 \pm 1$ & 48.15 & 43.77 \\
\hline $\mathrm{TiO}_{2}$ & 5.09 & 5.30 & 6.71 & 4.29 & 4.91 & $4 \pm 0.5$ & -2.62 & 6.76 \\
\hline $\mathrm{Al}_{2} \mathrm{O}_{3}$ & 16.56 & 18.29 & 22.08 & 13.63 & 15.67 & $11.4 \pm 1$ & 15.20 & 9.92 \\
\hline $\mathrm{Cr}_{2} \mathrm{O}_{3}$ & -0.56 & -0.55 & -0.08 & 0.37 & -0.28 & & 0.53 & 0.12 \\
\hline $\mathrm{FeO}$ & 21.09 & 21.78 & 20.33 & 20.64 & 18.75 & $19 \pm 1.5$ & 17.20 & 20.53 \\
\hline $\mathrm{MnO}$ & 0.23 & 0.22 & 0.37 & 0.21 & 0.25 & & 0.14 & 0.30 \\
\hline $\mathrm{MgO}$ & -2.14 & -3.56 & -6.69 & 6.68 & 4.64 & $6.1 \pm 0.5$ & 5.84 & 5.72 \\
\hline $\mathrm{CaO}$ & 15.89 & 16.18 & 18.83 & 12.56 & 12.88 & $11.5 \pm 0.4$ & 14.51 & 11.36 \\
\hline $\mathrm{Na}_{2} \mathrm{O}$ & 0.54 & 0.40 & 0.53 & 0.32 & 0.46 & & 0.51 & 0.73 \\
\hline $\mathrm{K}_{2} \mathrm{O}$ & 0.12 & 0.13 & 0.17 & 0.10 & 0.13 & & 0.12 & 0.13 \\
\hline $\mathrm{P}_{2} \mathrm{O}_{5}$ & 0.02 & 0.04 & 0.07 & 0.04 & 0.14 & & 0.43 & \\
\hline
\end{tabular}

Extracts, all obtained from measurement of Green et al. (1971, Figure 2). Slightly lower figures are indicated in their text, and these reduce, but do not cure, the discrepancies..

A pigeonite $139 \%$, spinel ${ }^{2} 1 \%$; B pigeonite ${ }^{1} 44 \%$, spinel ${ }^{2} 1 \%$; C olivine $326 \%$, pigeonite $43 \%$, spinel $^{5} 1 \%$; D olivine ${ }^{3} 18.6 \%$, pigeonite ${ }^{4} 30.7 \%$, spinel ${ }^{5} 0.7 \%$; E olivine ${ }^{6} 7 \%$, pigeonite $72 \%$, spinel $^{2} 1 \%$; F olivine ${ }^{8} 13 \%$, pigeonite ${ }^{9} 19 \%$, ilmenite ${ }^{10} 11 \%$.

$1=12021,1150^{\circ} \mathrm{C} ; 2=12009,1150^{\circ} \mathrm{C}$; from Green et al. (1971).

$4=12040 / 2,1137^{\circ} \mathrm{C} ; 7=12064 / 5,1114^{\circ} \mathrm{C} ; 8=12022 / 15,1129^{\circ} \mathrm{C} ; 9=12040 / 2,1137^{\circ} \mathrm{C}$; from Biggar et al. (1971).

$3=\mathrm{Fo}_{65}+0.5 \mathrm{Cr}_{2} \mathrm{O}_{3}, 0.3 \mathrm{CaO} ; 5=12064,6$ (Haggerty and Meyer, 1970).

$6=\mathrm{Fo}_{55} ; 10=12022,1103^{\circ} \mathrm{C}$ (unpublished).

Note that all solutions based on Green et al. (1971) visual estimates have attained conspicuously higher $\mathrm{Al}_{2} \mathrm{O}_{3}, \mathrm{CaO}$ concentrations than the analysed cotectic liquids which are already saturated with these components (as plagioclase). This results from gross overestimation of percentage of olivine, pyroxene. Solutions to 12021,12040 and 12065 show excessive depletion in $\mathrm{SiO}_{2}, \mathrm{MgO}$ because estimates of the amount of pyroxene present are excessive. In 12022, high $\mathrm{SiO}_{2}$, low $\mathrm{FeO}$ and negative $\mathrm{TiO}_{2}$ result from excessive ilmenite extract. Negative $\mathrm{Cr}_{2} \mathrm{O}_{3}$ values are not significant.

(4) Green et al.'s (1971) visual estimates of crystallinity yield values which are too high overall, and too high in pyroxene/olivine ratio, to apply to our experimental products. Residual liquid compositions, calculated by extracting their estimated percentages of crystals at plagioclase entry, frequently have negative components (Tables III and IV) have plagioclase-forming oxides well in excess of measured values in plagioclase-saturated cotectic residual liquids (Table IV), and are either grossly depleted, or are excessively rich in $\mathrm{SiO}_{2}$ relative to the analysed residual liquids (Table IV). These discrepancies place the calculated liquids, when in positive composition space at all, in regions where plagioclase is likely to crystallize first and for some interval before the appearance of olivine or pyroxene (Figures 5 and 12).

(5) Similar criticisms apply to Ringwood's (1970) estimate of $30-50 \%$ crystallization 


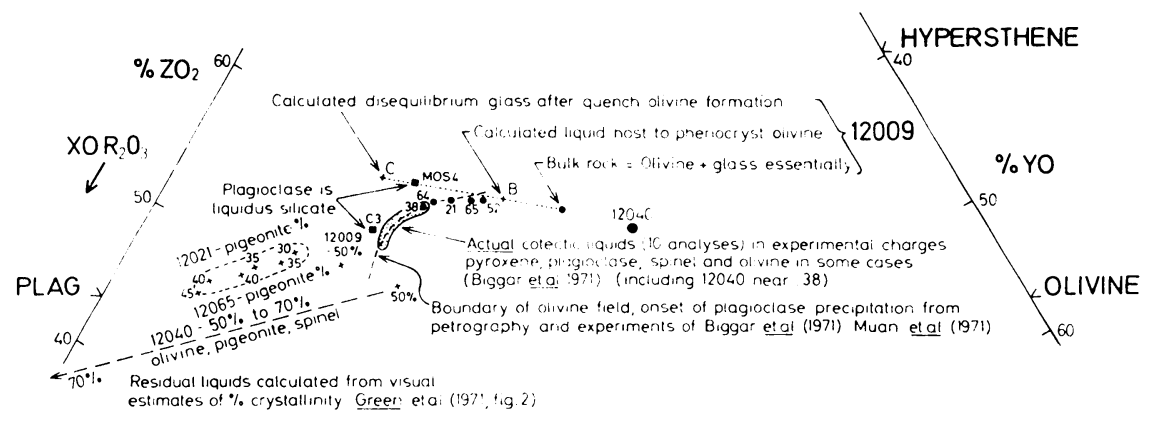

Fig. 5. Projection from diopside into the plagioclase-olivine-hypersthene-(silica) plane, of selected experimentally investigated natural and synthetic Apollo 12 materials, and analysed plagioclasesaturated liquids, to contrast with alleged plagioclase-saturated liquids, calculated by subtracting visual estimates of percentages of crystals in experimental charges. MOS 4 is from Muan et al. (1971). Calculated compositions with negative $\mathrm{MgO}$ plot within the figure provided there is sufficient $\mathrm{FeO}$ to compensate. The result would be unaffected by altering the $\mathrm{Fe} / \mathrm{Mg}$ ratio in the pyroxene or olivine extracted in this projection.

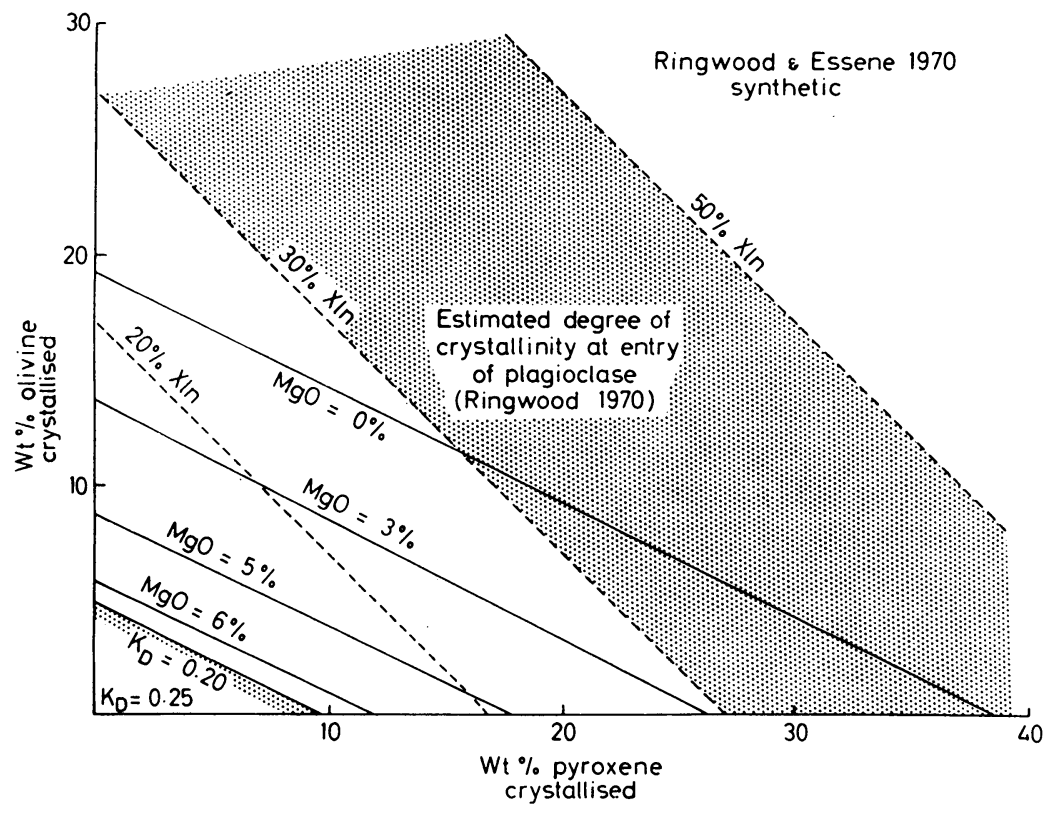

Fig. 6. Graphical presentation of results of extraction of $3 \%$ armalcolite (which reduces $\mathrm{TiO}_{2}$ to cotectic levels at acceptable $K_{D}$ and $\mathrm{MgO}$ figures) and variable combinations of olivine and pyroxene (Ringwood and Essene, 1970; Tables I(i), II(iii) and III, col. 1) from a synthetic Apollo 11 composition, contoured for resultant $K_{D}$ olivine-liquid distribution coefficients, residual $\mathrm{MgO}$ in liquid, and total percentage of crystalline material present. High crystallinity is incompatible with acceptable $K_{D}$ values and observed $\mathrm{MgO}$ contents of 6-7\% (Biggar et al., 1971; Table VI). 
TABLE V

Apollo 11 lavas, cotectic liquid composition calculations

\begin{tabular}{lrrrrrr} 
& \multicolumn{1}{c}{ I } & \multicolumn{1}{c}{ II } & \multicolumn{1}{c}{ III } & \multicolumn{1}{c}{ IV } & \multicolumn{1}{c}{ V } & \multicolumn{1}{c}{ VI } \\
\hline $\mathrm{SiO}_{2}$ & 42.60 & 43.00 & 44.89 & 44.09 & 40.69 & 40.76 \\
$\mathrm{TiO}_{2}$ & 8.86 & 8.76 & 8.25 & 8.31 & 11.92 & 11.98 \\
$\mathrm{Al}_{2} \mathrm{O}_{3}$ & 11.01 & 10.31 & 9.95 & 10.09 & 7.78 & 7.84 \\
$\mathrm{Cr}_{2} \mathrm{O}_{3}$ & 0.12 & 0.12 & 0.15 & 0.09 & 0.34 & 0.39 \\
$\mathrm{FeO}$ & 17.78 & 17.68 & 16.83 & 18.13 & 19.49 & 19.54 \\
$\mathrm{MnO}$ & 0.28 & 0.31 & 0.22 & 0.28 & 0.28 & 0.29 \\
$\mathrm{MgO}$ & 6.12 & 6.47 & 5.39 & 5.92 & 7.51 & 7.56 \\
$\mathrm{CaO}$ & 12.41 & 11.34 & 12.73 & 11.07 & 10.76 & 10.81 \\
$\mathrm{Na}$ & 0.43 & 0.72 & 0.66 & 0.62 & 0.51 & 0.45 \\
$\mathrm{~K}_{2} \mathrm{O}$ & 0.09 & 0.37 & 0.39 & 0.59 & 0.30 & 0.43 \\
$\mathrm{P}_{2} \mathrm{O}_{5}$ & 0.12 & & 0.24 & & 0.18 & \\
$\mathrm{~S}$ & 0.18 & & & & 0.23 &
\end{tabular}

I - Apollo 11 ophitic group average (Compston et al., 1970) minus $5 \%$ ilmenite, $4 \%$ olivine, $0.5 \%$ spinel.

II - Cotectic liquids, average from 10017, 10084 (Biggar et al., 1971, Table VI); note $\mathrm{CaO}, \mathrm{Al}_{2} \mathrm{O}_{3}$ lower than in $\mathrm{I}$.

III - Apollo 11 intersertal group average, (Compston et al., 1970) minus 10\% ilmenite, $4 \%$ olivine, $4 \%$ pigeonite, $4 \%$ augite.

IV - 10017 residual liquid at $1133^{\circ} \mathrm{C}$ (Biggar et al., 1971), note $\mathrm{CaO}$, lower than in III.

V - Apollo 11, 10017 rock (Compston et al., 1970).

VI - Best fit to V using 10017 liquid at $1133^{\circ} \mathrm{C}$ plus $0.8 \%$ olivine (Fo65), $0.2 \%$ spinel $(10020-40$ Haggerty et al., 1970), $10.1 \%$ ilmenite (10020-40), 19.8\% augite (10024-23/grain 14 Kushiro and Nakamura 1970$)$ and $-2.6 \%$ pigeonite $(10024-23 /$ grain 14$): K_{D}$ ol $-\mathrm{lq}=0.26$. Negative pigeonite shows that a more calcic augite should have been used.

of Apollo 11 lavas before plagioclase entry (Figure 6); excessive depletion, in $\mathrm{MgO}$ and, above all, in $\mathrm{MgO}$ relative to $\mathrm{FeO}$ result. Petrological observation (James and Jackson 1970; see Biggar et al., 1971, p. 637) and various calculations (Table V and Figure 7) based on analysed residual liquids from experiments carried out on the natural rock samples, indicate that the Apollo 11 ophitic group (B) lavas precipitated plagioclase and 4 or 5 other crystalline phases when only $10 \%$ crystalline. The Apollo 11 intersertal group (A) lavas were nearer $25 \%$ crystalline on reaching the same condition. New data (Prinz et al., 1971) for the average composition of lithic fragments at the Apollo 11 site yield more representative average compositions of the high potassium and low potassium lavas groups which are strikingly close in composition to the average of two cotectic liquids analysed by Biggar et al. (1971), Table VI. Selected oxide figures, listed in the above sample order, are: $\mathrm{SiO}_{2} 42.8,42.9,43.0 ; \mathrm{TiO}_{2}$ 9.6, 8.7, 8.8; $\mathrm{Al}_{2} \mathrm{O}_{3}$ 10.6, 11.8, 10.3; $\mathrm{FeO} 18.0,17.0,17.7 ; \mathrm{MgO}$ 7.0, 7.2, 6.5; $\mathrm{CaO}$ 10.7, $11.4,11.3$. These compositions will reach the plagioclase-precipitation cotectic at still lower amounts of crystallization.

(6) Primary magmas produced by partial melting of unknown source rocks at an elevated pressure are randomly chosen compositions with respect to the low pressure phase equilibria. The probability of such compositions exhibiting the close approach to low pressure cotectic character actually observed in Apollo 11 and 12 lavas by 


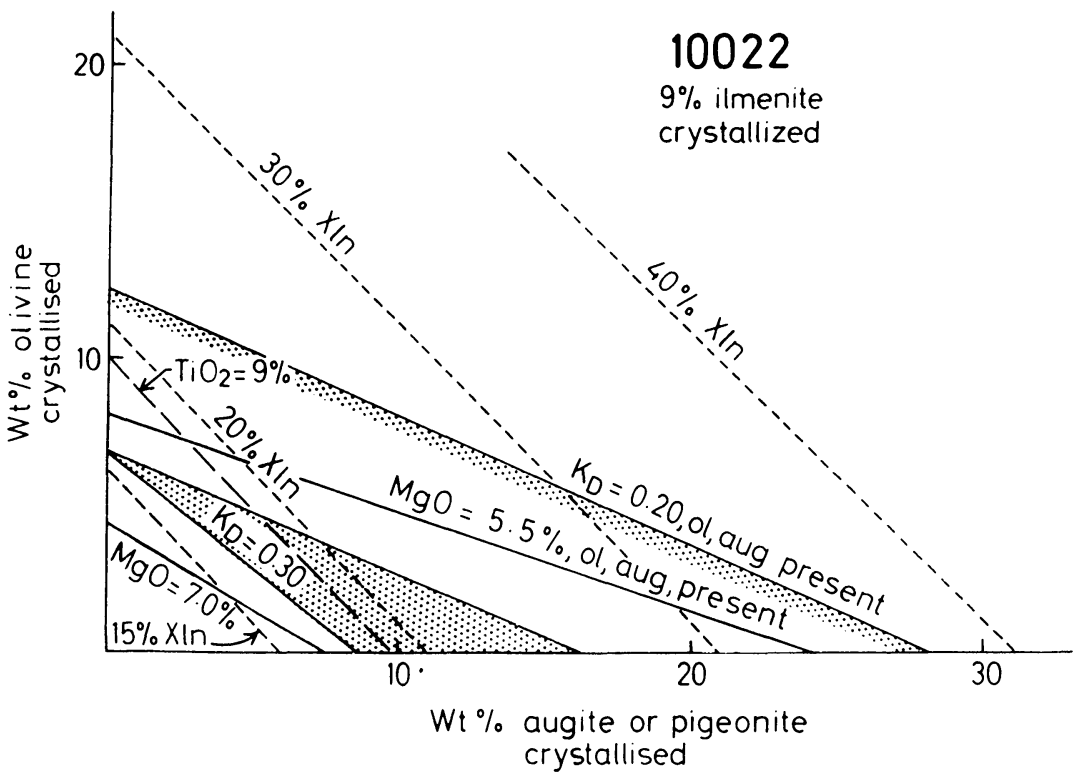

Fig. 7. Similar presentation to Figure 6 for rock 10022, using analysed mineral (core) compositions (Kushiro and Nakamura 1970) showing (shaded field) a range of acceptable $\mathrm{MgO}$ contents in the residual liquid at acceptable $K_{D}$ values consistent with $15-25 \%$ crystallization. Results with $K_{D}<0.20$ are deemed unacceptable. Alternative sets of $K_{D}$ and $\mathrm{MgO}$ contours result from the choice of pigeonite or augite as the pyroxene crystallizing.

TABLE VI

Probabilities, $\phi$, of observed approaches to cotectic behaviour being coincidence

\begin{tabular}{|c|c|c|c|c|c|c|c|c|c|c|c|c|}
\hline \multirow[t]{2}{*}{ Source } & \multirow{2}{*}{\multicolumn{3}{|c|}{$\begin{array}{l}\text { Laki } 1783 \\
\text { Iceland }\end{array}$}} & \multirow{2}{*}{\multicolumn{3}{|c|}{$\begin{array}{l}\text { Kilauea } \\
\text { Hawaii }\end{array}$}} & \multicolumn{4}{|c|}{ Apollo 11} & \multicolumn{2}{|c|}{ Apollo 12} \\
\hline & & & & & & & Ophitic & & Interser & & 12038 & 12064 \\
\hline$P^{*}$ & & 3 & & & 3 & & 6 & & 6 & & 4 & 5 \\
\hline$X$ & & 0.10 & & & 0.05 & & 0.10 & & 0.25 & & 0.05 & 0.10 \\
\hline C & 4 & 6 & 10 & 4 & 6 & 10 & 7 & 9 & 7 & 9 & 8 & 8 \\
\hline$\phi$ & 0.028 & 0.033 & 0.22 & 0.007 & 0.022 & 0.071 & 0.00005 & 0.0004 & 0.0046 & 0.027 & 0.0036 & 0.0027 \\
\hline
\end{tabular}

Calculated from the relationship

$$
\phi=\sum_{P=P^{\star}}^{P=C} \frac{(C-1) !}{(P-1) !(C-P) !} \cdot X^{(P-1)}(1-X)^{(C-P)}
$$

where $C=$ number of significant components, $P^{*}=$ number of crystalline phases present, $X=$ weight fraction present as crystals. This relationship is approximately true provided liquid loci are not strongyl curved. 


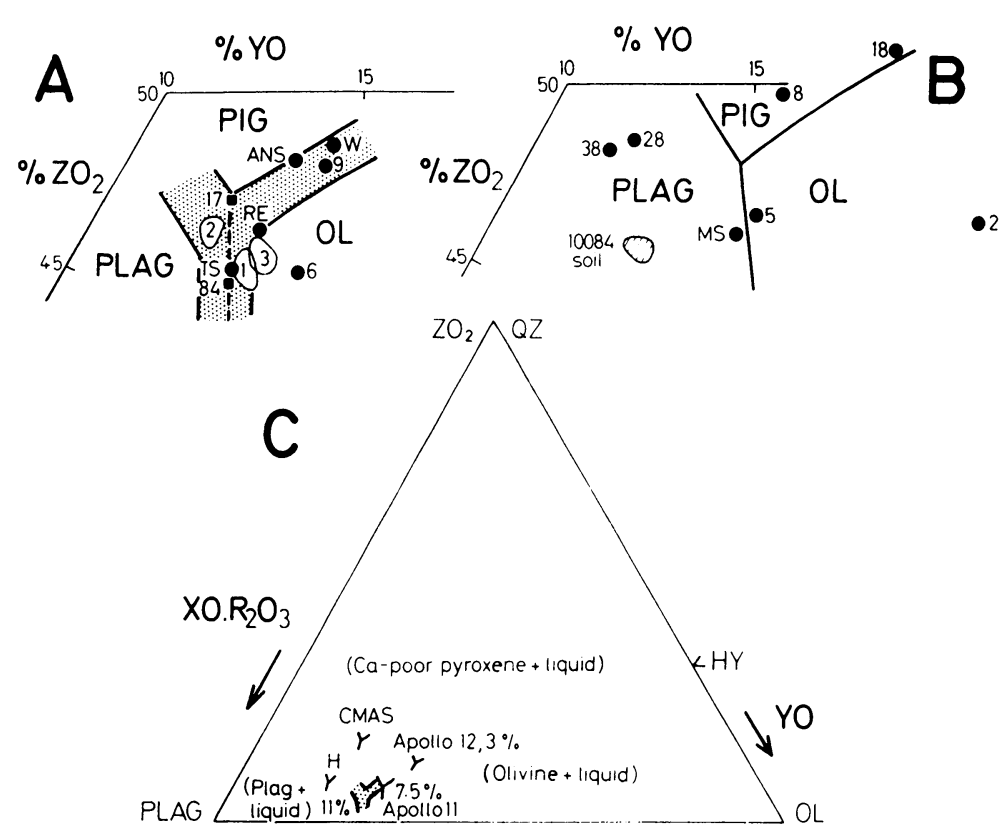

Fig. 8. Projection (O'Hara, 1968; Jamieson, 1970) from diopside into the plane plagioclase-olivinehypersthene (quartz) showing the boundaries between the primary liquidus phase volumes of plagioclase, pigeonite and olivine as deduced from experimental and petrographic data for (A) synthetic and natural compositions of high $\mathrm{TiO}_{2}$ content, $(\sim 11 \pm 1 \%)$ making no allowance for $\mathrm{TiO}_{2}$-rich phase crystallization at liquidus, and for (B) intermediate $\mathrm{TiO}_{2}$ content $(\sim 7.5 \pm 1.5 \%)$. Compositiors 2, 5, 6, 8, 9, 18, 28, 38 from O' Hara et al. (1970); ANS from Anderson et al. (1970); MS from Muan and Schairer (1971); RE from Ringwood and Essene (1970); TS from Tuthill and Sato (1970); W from Weill et al. (1970). Numbered fields enclose analyses of lavas of ophitic groups 1,2; intersertal group 3, and 10084 soil as in Biggar et al. (1971, Figure 8), while 17,84 mark the analysed residual liquids of rocks 10017,10084 at the $8.75 \pm .5 \mathrm{TiO}_{2}$ level (Biggar et al., 1971, Table VI). Figure 7c compares the deduced cotectic liquid compositions with the analogous cotectic liquids in the Apollo 12 rocks at $\sim 3 \% \mathrm{TiO}_{2}$; in Hawaiian tholeiitic lavas $(\mathrm{H})$; and in the iron, sodium and titanium free system $\mathrm{CaO}-\mathrm{MgO}-\mathrm{Al}_{2} \mathrm{O}_{3}-\mathrm{SiO}_{2}$ (CMAS).

coincidence is measured in parts per ten thousand to parts per hundred at best (Table VI). When the new average compositions of Apollo 11 lavas (Prinz et al., 1971), and the near coincidence of cotectic temperature and eruption temperature is taken into account these probabilities decline still further.

(7) Cotectic liquid compositions are best established by bracketing, i.e. by finding closely related compositions lying in different primary liquidus phase volumes. This has been done for Apollo 11 compositions (O'Hara et al., 1970, Figures 2, 3; Biggar et al., 1971, Figures 8, 9; and this paper Figures 8, 9 and 10). A bracket on plagioclase entry was established by two laboratories from synthetic compositions resembling Apollo 12 lavas (Figure 5). Cotectic character can also be established by analysing the cotectic liquids and other experimentally produced phases, and thence proving low percentage crystallinity by calculation, as done here (Tables II, III and V). Least 


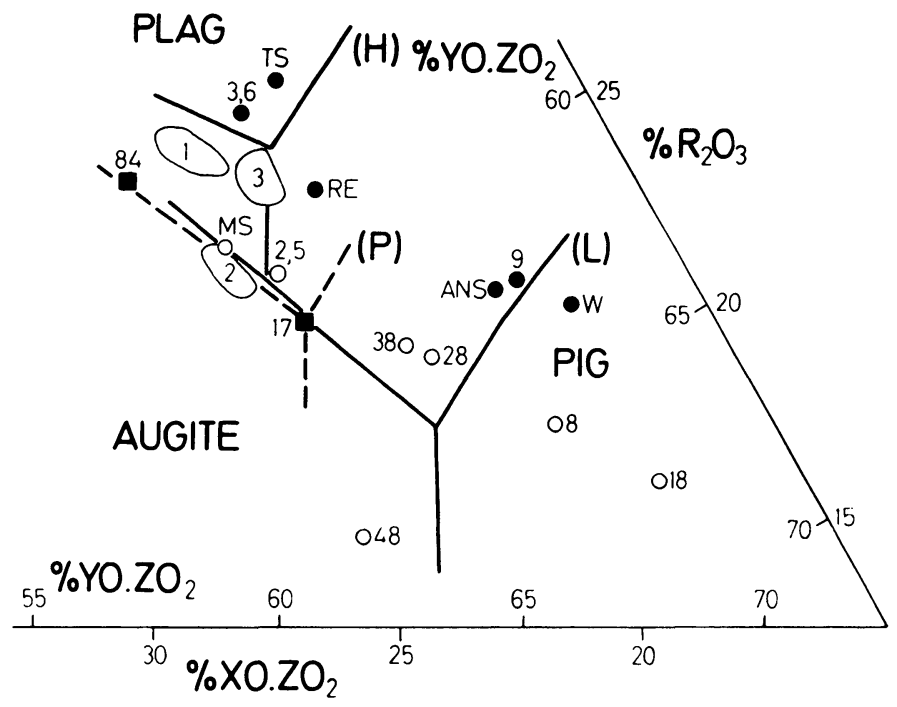

Fig. 9. Part of the projection from olivine into the plane hypersthene ( $\mathrm{YO}^{\mathrm{ZO}} \mathrm{ZO}_{2}$ )-wollastonite $\left(\mathrm{XO} . \mathrm{ZO}_{2}\right)-\mathrm{R}_{2} \mathrm{O}_{3}$, treating the same data as in Figure 8 to deduce the apparent boundaries between the plagioclase, augite and pigeonite crystallization fields at saturation with olivine, when $\mathrm{TiO}_{2}$ contents are high $(\sim 11 \pm 1 \%$; boundaries $(\mathrm{H})$, solid circle data points and natural rock, fields 1,3 ; drawn without allowance for $\mathrm{TiO}_{2}$-rich phase crystallization), or low $(\sim 7.5 \pm 1.5 \%$, boundaries $\mathrm{L}$, open circle data points), and the preferred position $(\mathrm{P})$ at simultaneous saturation with $\mathrm{TiO}_{2}$-rich oxides and the silicates, $\mathrm{TiO}_{2} \sim 8.75 \pm 0.5 \%$ from probe analyses of experimentally produced residual liquids, and ophitic lavas group 2 (compare Biggar et al., 1971, Figure 9). 10084 soil (not shown) falls in the plagioclase field of the (L) boundaries between MS, 84 and 1.

satisfactory is the indirect method of estimating, visually or otherwise, the percentage of crystals present on reaching cotectic crystallization, because it carries no internal check on consistency, and is susceptible to subjective and systematic errors in arriving at the estimates, particularly in fine grained products (plate I; D, E).

Close approach to cotectic composition is often, but not necessarily, accompanied by the appearance of many crystalline phases within a narrow temperature interval. However, neither the size of the temperature interval over which a number of crystalline phases appear, nor the size of the temperature interval between liquidus and solidus are criteria of closeness to cotectic composition. O'Hara et al. (1970) were incorrectly criticized (Ringwood, 1970, p. 6455) directly or by implication for the use of such criteria, but neither the abstract from which Ringwood drew his quotations, nor the full statement (O'Hara et al., 1970, pp. 695, 704), is written in terms which excuse such a misrepresentation. The only authors who, to our knowledge, have attempted to utilize the size of the temperature interval as a criterion in this respect are Green et al. (1971, p. 608), in search of criticisms of Biggar et al. (1971), and Ringwood and Green (1971).

(8) The techniques used in the Edinburgh laboratory did not reveal a spuriously close approach to cotectic character in the random compositions represented by 


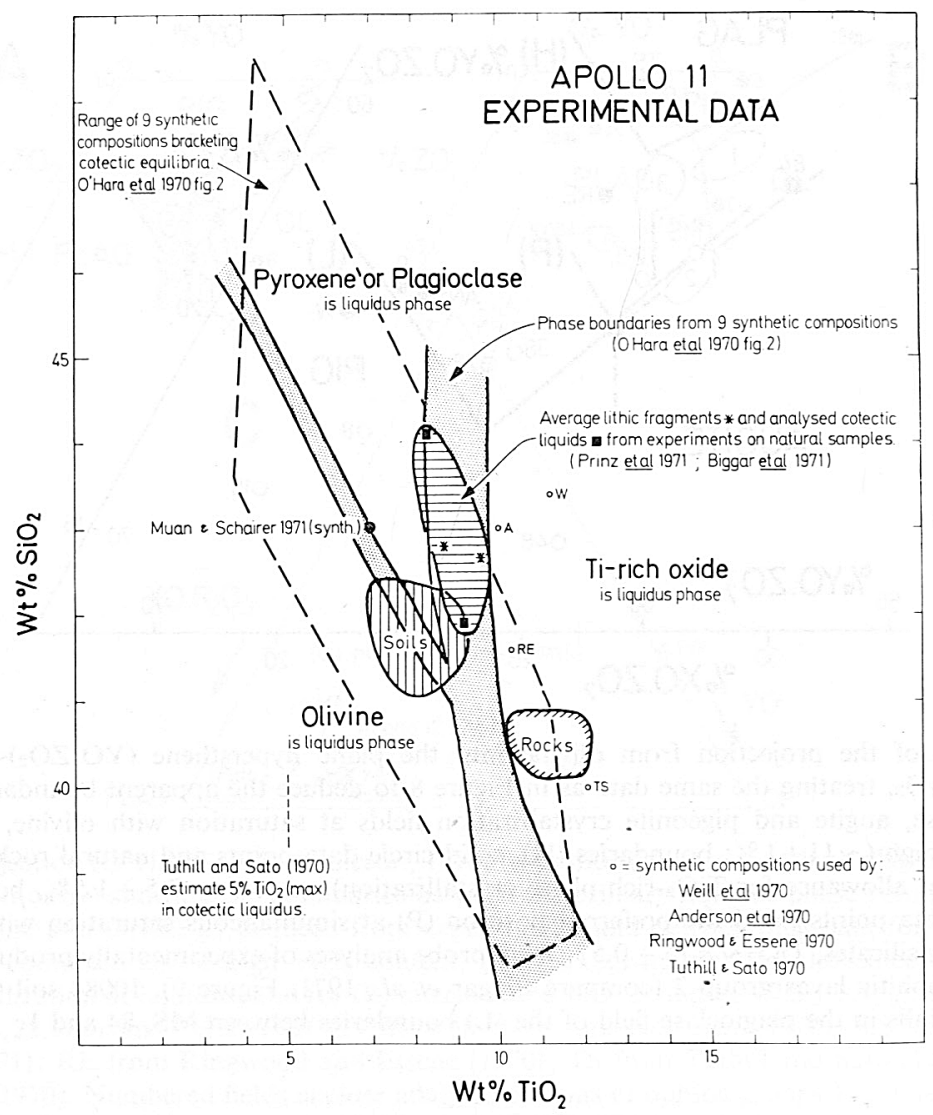

Fig. 10. Simplistic $\mathrm{SiO}_{2} \mathrm{v} . \mathrm{TiO}_{2}$ representation of liquidus fields, average rock compositions and cotectic liquid compositions encountered in Apollo 11 natural rocks and synthetic simulations.

(N. B. Use of a higher oxygen fugacity caused plagioclase to appear as liquidus phase at the centre of the figure).

erroneous Apollo 12 analyses (Biggar et al., 1971), nor has it revealed it in a suite of Reunion lavas known to depart somewhat from low pressure cotectic liquid compositions in their natural crystallisation (D. J. Humphries, in press). These techniques do, however, determine cotectic liquid compositions and temperatures identical (e.g. Figure 11) with those reported by other laboratories also engaged in long-term programs of atmospheric pressure experiments in systems of industrial and geological interest. With these techniques we also observe a close approach to cotectic character in the Laki fissure eruption (J. D. Bell and D. J. Humphries, in press) whose petrography demonstrates eruption with three phenocryst species when as little as $5 \%$ crystalline. Similar demonstrations of objectivity and applicability to natural circumstances are available for the technique used by Muan et al. (1971), these authors also remarking on the low degree of crystallinity at plagioclase entry.

(9) Available data from relevant synthetic systems (Figure 12) supports the bound- 


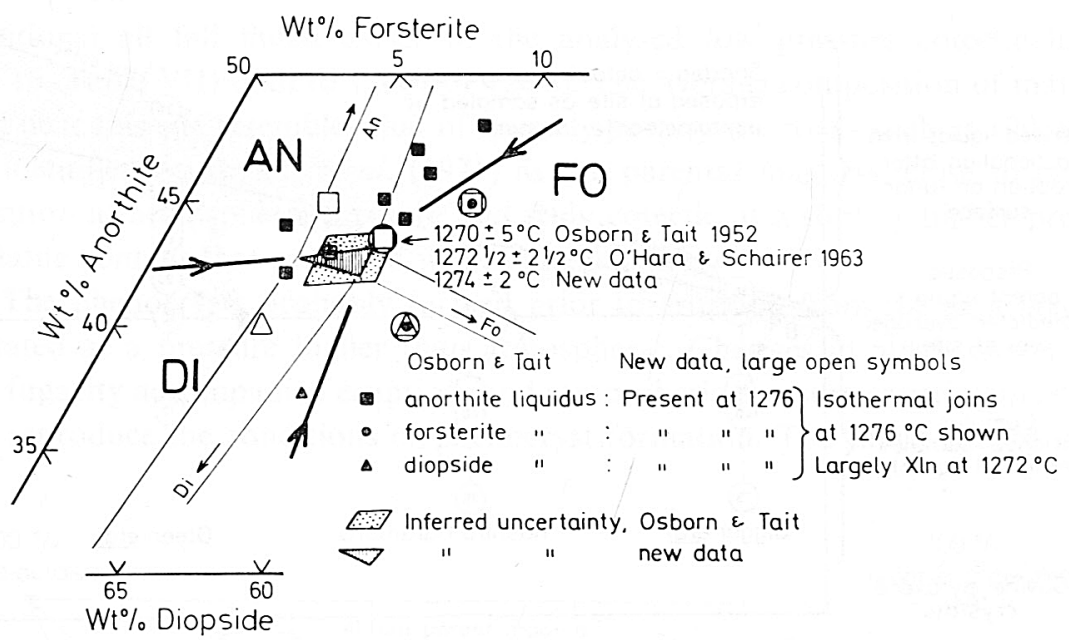

Fig. 11. Part of the plane anorthite-diopside-forsterite comparing atmospheric pressure phase boundaries (Osborn and Tait, 1952), and results for five compositions made and run in the Edinburgh laboratory illustrating close interlaboratory agreement on cotectic composition and temperature.

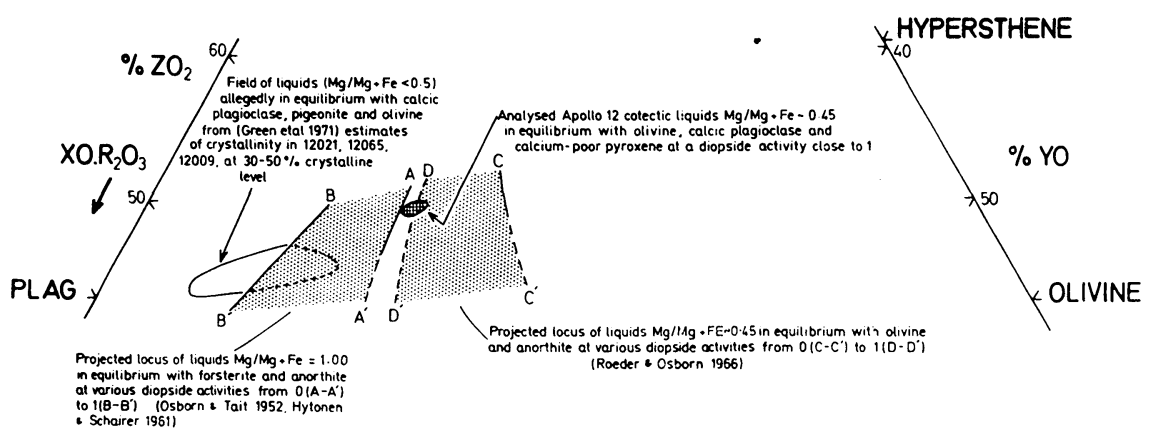

Fig. 12. Projection from diopside (as in Figure 6) into the plane plagioclase-olivine-hypersthene (silica) showing the loci of liquids in equilibrium in synthetic systems with olivine, plagioclase and one or two pyroxenes. Diopside activity has been set at zero in the olivine-plagioclase-silica plane, and at 1 when calcium-rich clinopyroxene coexists with olivine and plagioclase.

ary marking onset of plagioclase crystallisation found by Biggar et al. (1971) and Muan et al. (1971) in Apollo 12 compositions.

(10) Interpretation of the phase equilibria and lava chemistry turns on the average rock composition at the Apollo 12 site (Figures 13, and 14). The fundamental implications of this decision for lunar petrogenesis are illustrated by Figure 15. The hypothesis that 12009 or 12040 represent the parental magma at this site is untenable. The compositions of the average fines; average basaltic lithic fragments from the solls; impact melted glass fragments least affected by alkali depletion; and even the weighted average of the large rocks distributed for analysis (liable to bias towards extreme 


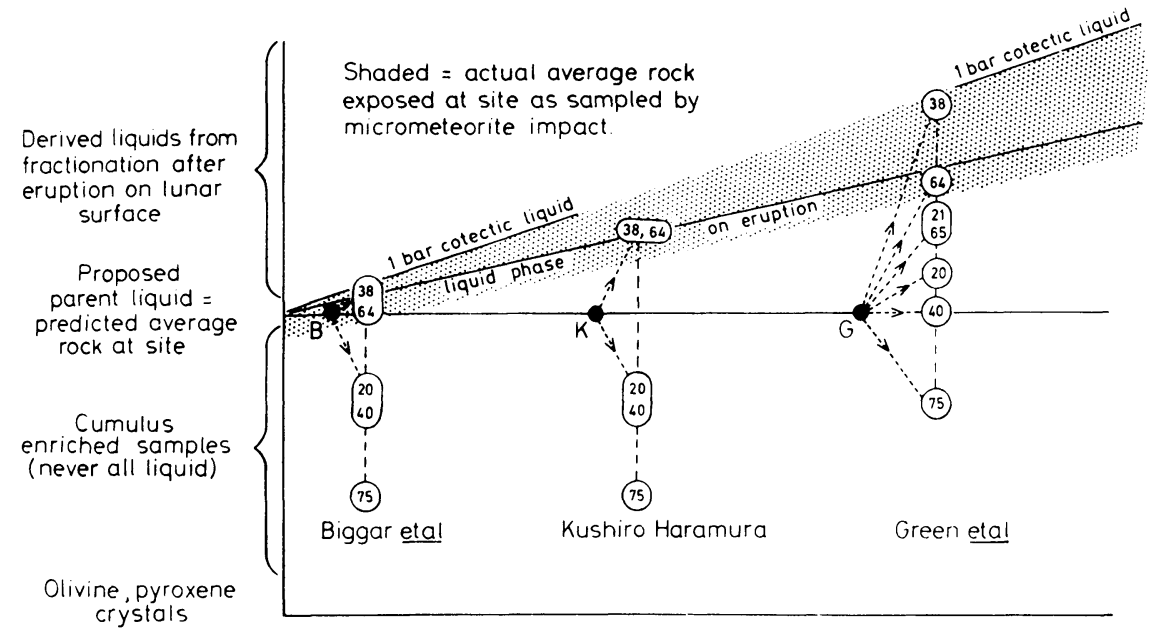

Fig. 13. Graphical summary of alternative interpretations of Apollo 12 site petrogenesis and their implications. The status of 12009 , also regarded by Green et al. (1971) as possible parental liquid is discussed in the text. The alternative status of Apollo 12 rock samples (indicated by final two digits of sample numbers) in the three interpretations is apparent.

\section{PREFERRED MODEL}

Impacts sample whole sequence. Glass splash, as fragments, spheres, or large lumps chilled from $>1200^{\circ} \mathrm{C}$, reflects average composition

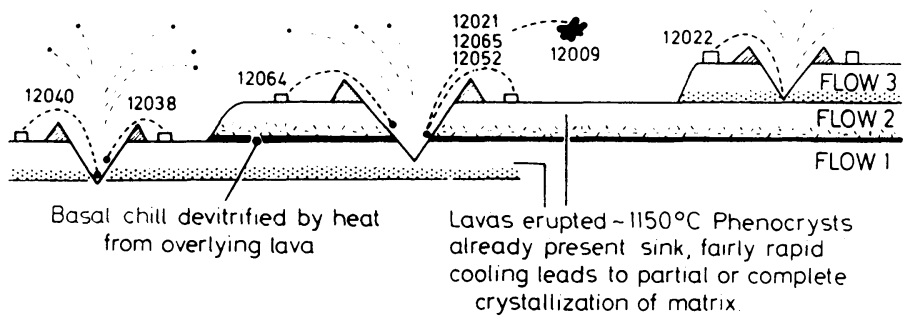

\section{A REJECTED ALTERNATIVE}

impacts sample only uppermost parts of flows (WHY?), obtaining selective sample of phenocryst depleted tops to flow.

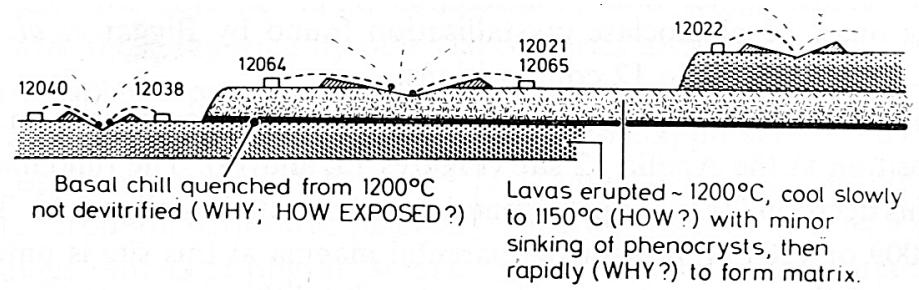

Fig. 14. Schematic cross-sections corresponding with two extreme alternatives from Figure 13, illustrating their implications for Apollo 12 site geology. Individual globs of impact melt depart from average rock composition, but on average short travelled material reflects rock average. 
compositions) all fall much closer to the analysed low pressure cotectic liquids (Figure 16, Table VII) than to 12009 or 12040 . The average composition of materials exposed near this site resembles that of sparsely porphyritic rocks such as 12038 , and 12064, identified by Biggar et al. (1971) as the parental magmas, close to cotectic composition at atmospheric pressure and truly cotectic at a slightly higher pressure and volatile content that prevailed within the lava lake.

(11) The phenocrysts probably formed prior to eruption from the lava lake and precipitated at a pressure higher than atmospheric. Changes in alkali content and oxygen fugacity accompanied eruption, and atmospheric pressure experiments do not exactly reproduce the conditions of phenocryst formation. Too much should not be

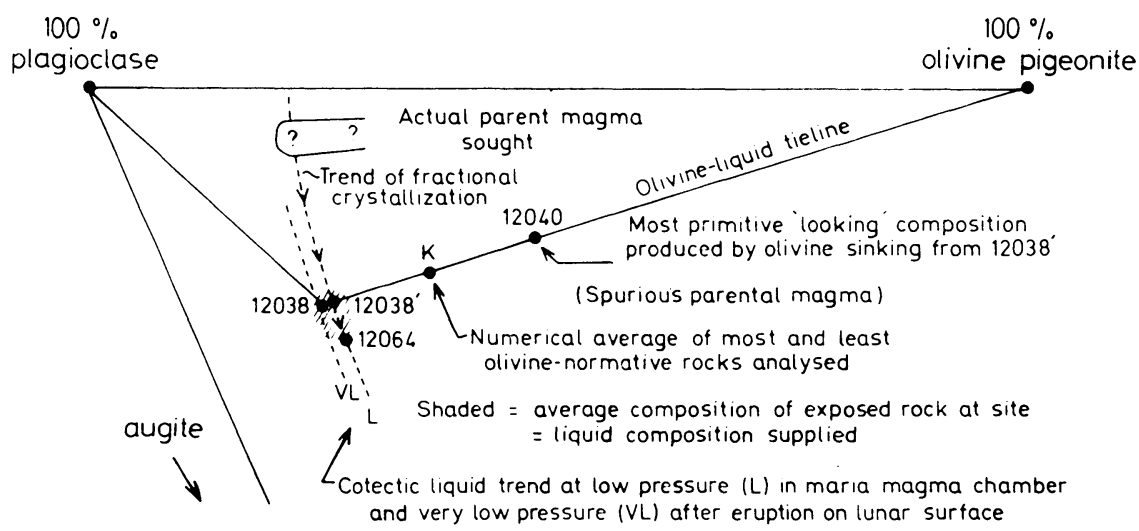

Fig. 15. Simplified phase diagram illustrating the experimental significance of the alternative interpretations of Figure 13, and their implications for studies of the lunar interior.

TABLE VII

\begin{tabular}{|c|c|c|c|c|c|c|c|c|c|}
\hline & $\mathrm{SiO}_{2}$ & $\mathrm{TiO}_{2}$ & $\mathrm{Al}_{2} \mathrm{O}_{3}$ & $\mathrm{Cr}_{2} \mathrm{O}_{3}$ & $\mathrm{FeO}$ & $\mathrm{MgO}$ & $\mathrm{CaO}$ & $\mathrm{Na}_{2} \mathrm{O}$ & $\mathrm{K}_{2} \mathrm{O}$ \\
\hline $\begin{array}{l}\text { verage basaltic lithic } \\
\text { agments }^{\mathrm{a}}\end{array}$ & 47.2 & 3.0 & 14.0 & $\operatorname{tr}$ & 15.8 & 8.0 & 10.9 & 0.5 & 0.2 \\
\hline 2038 rock $^{\text {b }}$ & 47.1 & 3.3 & 13.0 & - & 17.7 & 6.6 & 11.4 & 0.7 & 0.1 \\
\hline 10 glass $^{a}$ & 40.3 & 3.5 & 7.1 & 0.6 & 23.2 & 16.6 & 8.0 & $\operatorname{tr}$ & $\operatorname{tr}$ \\
\hline 2040 rock $^{\text {b }}$ & 43.9 & 2.7 & 7.4 & 0.7 & 20.8 & 16.1 & 7.9 & 0.2 & $\operatorname{tr}$ \\
\hline 9 glass $^{a}$ & 43.1 & 4.4 & 8.5 & 0.3 & 23.0 & 11.0 & 9.4 & 0.4 & 0.2 \\
\hline 2009? impact vitrophyrec & 45.0 & 2.9 & 8.6 & 0.5 & 21.0 & 11.5 & 9.4 & 0.2 & 0.1 \\
\hline
\end{tabular}

${ }^{a}$ Keil et al. (1971); $\quad{ }^{b}$ Kushiro and Haramura (1971); c Compston et al. (1971).

(1) Comparison of average of 28 basaltic lithic fragments in Apollo 12 soil with rock 12038 (suggested parental cotectic liquid to eruptive sequence) showing similarity; average fragments are not similar to 12040,12009 , below, in $\mathrm{SiO}_{2}, \mathrm{Al}_{2} \mathrm{O}_{3}, \mathrm{Cr}_{2} \mathrm{O}_{3}, \mathrm{MgO}$ or $\mathrm{CaO}$.

(2) Comparison of impact melted glass fragment in Apollo 12 soil, with rock 12040, a coarsely crystalline potential target rock formed by crystal accumulation.

(3) Comparison of impact melted glass fragment in Apollo 12 soil with rock 12009, a largely glassy sample with thermal history more akin to that of impact melts than to the great majority of the igneous rock samples. 
TABLE

Summary of experimental data relevant to entry of

\begin{tabular}{|c|c|c|c|c|}
\hline Run No. & Samples & Temperatures ${ }^{\circ} \mathrm{C}$ & $\begin{array}{l}\text { Time } \\
\text { (h) }\end{array}$ & $\begin{array}{l}\text { Starting material as } \\
\text { loaded }\end{array}$ \\
\hline
\end{tabular}

\section{A. Reversals}

$\begin{array}{ll}031 & 12021,38,52,64,65 \\ 032 & 12018,20,38,40 \\ 033 & 12018,20,38,40 \\ 035 & 12018,20,38,40 \\ & \\ 111 & 12020 \\ 112 & 12020,12038 \\ 117 & 12018,20,38,40\end{array}$

$\begin{array}{ll}1144 ; 1137 & 5 ; 5 \\ 1167 ; 1156 & 5 ; 5 \\ 1166 ; 1153 & 4 ; 12^{\mathrm{a}} \\ 1162 ; 1153 & 4 \frac{1}{2}^{\mathrm{g}} ; 16 \\ & 5 ; 5 \\ 1167 ; 1156 & 4 ; 12^{\mathrm{a}} \\ 1166 ; 1153 & 4 \frac{1}{2}^{\mathrm{g}} ; 16\end{array}$

rock powder rock powder rock powder rock powder

B. Syntheses from 'different' starting materials (pseudoreversals)

\begin{tabular}{|c|c|c|c|c|}
\hline 030 & 12038 & 1167 & 5 & rock powder \\
\hline 034 & $12018,20,38,40$ & 1153 & $6 \frac{1}{2}$ & rock powder \\
\hline 036 & $12018,20,38,40$ & 1153 & 72 & rock powder \\
\hline 113 & 12020,12038 & $1300 ; 1153$ & $24 ; 6 \frac{1}{2}$ & glass $^{b}, \mathrm{c}$ \\
\hline 114 & 12020 only & $1340 ; 1153$ & $1 \frac{1}{3} ; 6 \frac{1}{2}$ & glass $^{\mathrm{b}, \mathrm{c}}$ \\
\hline 116 & $12018,20,38,40$ & 1153 & 72 & glass $^{b, c}$ \\
\hline 015 & $12022,38,52$ & 1129 & $1 \frac{1}{2}$ & rock powder \\
\hline 016 & $12022,38,52$ & $1300 ; 1129$ & $1 ; 1 \frac{1}{2}$ & glass $^{\mathrm{b}, \mathrm{c}}$ \\
\hline 017 & $12022,38,52$ & $1300 ; 1129$ & $1 ; 1 \frac{1}{2}$ & glass $+5 \%$ rock \\
\hline 109 & 12052 & $1300 ; 1041$ & $24 ; 0.16$ & glass $^{b}$ \\
\hline 110 & $12020,38,52,64$ & $1340 ; 1041$ & $1 ; 0.16$ & glass $^{\mathrm{b}}$ \\
\hline$?$ & n. d. & n. d. & n. d. & glass $^{c, d}$ \\
\hline ? & n. d. & n. d. & n. d. & glass $^{\mathrm{c}, \mathrm{d}}$ \\
\hline ? & n. d. & n. d. & n. d. & devitrified glass ${ }^{e}$ \\
\hline ? & n. d. & n. d. & n. d. & devitrified glass $\mathrm{e}$ \\
\hline
\end{tabular}

C. Charges converted to liquid, or mainly liquid then temperature lowered substantially ${ }^{\mathrm{f}}$
006
$18,20,21,22,38,40$, $52,64,65$
$1250 ; 1154$
$1 ; 4 \frac{1}{2}$
rock powder

glass $\left(1340,1 \frac{1}{3} \mathrm{hr}\right)^{\mathrm{b}, \mathrm{c}}$ glass $\left(1340,1 \frac{1}{3} \mathrm{hr}\right)^{\mathrm{b}, \mathrm{c}}$ glass $\left(13301 \frac{1}{4} \mathrm{hr}\right)^{\mathrm{b}}$ c $\mathrm{c}$

\begin{tabular}{|c|c|c|c|c|}
\hline 013 & $\begin{array}{l}18,20,21,22,38,40, \\
52,64,65\end{array}$ & $1306 ; 1110-1127$ & $1 ; 1$ & rock powder \\
\hline 101 & $12022,38,64$ & $1228 ; 1121$ & 1,24 & rock powder \\
\hline 102 & $12022,38,64$ & $1225 ; 1119$ & 1,1 & rock powder \\
\hline 104 & $12022,38,64$ & $1320 ; 1116$ & 2,1 & rock powder \\
\hline $\begin{array}{l}\text { Muan and Schairer } \\
\text { (1971) }\end{array}$ & Apollo 11 synthetic & $1200 ; 1090$ & n. d. & devitrified glass \\
\hline $\begin{array}{l}\text { Roedder and } \\
\text { Weiblen (1970) }\end{array}$ & $\begin{array}{l}\text { Inclusions in } \\
\text { olivine }\end{array}$ & $\begin{array}{l}>1200 ; 1125 / \\
1065\end{array}$ & many hours & glass \\
\hline
\end{tabular}

\footnotetext{
All Edinburgh experiments carried out at $\mathrm{fO}_{2}$ of $\mathrm{Fe} / \mathrm{FeO}$ equilibrium.

${ }^{a}$ held $3 \mathrm{~h}$ each at 1159,1156 during temperature reduction.

b glass prepared, quenched, then reloaded. Picritic samples still retain some olivine.

c glass may have devitrified while coming up to temperature (see 109, 110).
} 
VIII

plagioclase and use of glass as starting material

Comments

plagioclase destroyed except in 12038; renucleated in all.

plagioclase destroyed; renucleated 20,38 only.

plagioclase destroyed; renucleated 12038 only.

plagioclase destroyed; renucleated in all four samples (less than in 034)

plagioclase renucleated

plagioclase renucleated in both

plagioclase renucleated in all samples

trace olivine only

well distributed scarce plagioclase

well distributed scarce plagioclase

plagioclase present in 12038

plagioclase present

plagioclase present, pyroxene with multiple twinning

( same phases present in all;

plagioclase less abundant in products from

glass bearing starting materials

(variably devitrified on reaching $1041^{\circ} \mathrm{C}$;

charges spent 9 mins $>1000^{\circ} \mathrm{C} ; 17$ mins $>700^{\circ} \mathrm{C}$;

plagioclase in some. See text.

(Green et al. (1971) "confirmed temperature

of disappearance of

plagioclase": claimed as reversal.

(No plagioclase; large pyroxene prisms regenerated, showing curving cracks, some polysynthetic twinning, in 12020, 40, 65

A few crystals free from cracks had straight extinction

No plagioclase; little pyroxene in $38,64\left(2-50^{\circ} \mathrm{C}\right.$ below

equilibrium entry).

No plagioclase in 12022 (contrast 016 )

No plagioclase in $12022,64\left(10-20^{\circ} \mathrm{C}\right.$ below equilibrium)

No plagioclase in any $\left(10-45^{\circ} \mathrm{C}\right.$ below equilibrium)

No plagioclase $\left(90^{\circ} \mathrm{C}\right.$ below equilibrium entry)

No plagioclase or pyroxene renucleation.

d glass prepared by few minutes heating at high temperature (Green, pers. comm).

e conditions of devitrification not stated.

' runs were kept in the furnace and not quenched, merely lowered to the second temperature quoted, and finally quenched.

g $2 \frac{1}{2} \mathrm{~h}$ at 1160 , then $2 \mathrm{~h}$ at 1162 , lowered in $1 \frac{1}{2} \mathrm{~h}$ to 1153 . 
made out of small differences in composition between experimentally produced liquidus phases and natural phenocryst cores, least of all when the phase in question is in reaction relationship with the liquid and effects leading to excessively magnesian residual compositions can come into play (O'Hara, 1963 p. 42). Those effects are likely to be most marked in rocks such as 12065 where the ratio of olivine resorbed to olivine precipitated is highest, and the occurrence of the most magnesian olivines within the reaction product (pigeonite; Green et al., 1971, p. 605) underlines the need for caution.

(12) A liquid such as 12064 can be derived by pigeonite + plagioclase dominated fractionation from liquid such as 12038 (Biggar et al., 1971, Table VII). Green et al. $(1971$, p. 611$)$ have not examined the data sufficiently closely in reaching their conclusions.

(13) 12009 existed as a liquid plus c. $9 \%$ olivine crystals at the lunar surface, and even that olivine may be a quenching product if Green et al. (1971 p. 601) are correct in identifying it as skeletal. This vitrophyre was very rapidly cooled from temperatures of c. $1200^{\circ} \mathrm{C}$ or possibly considerably higher, whereas most other rocks at the site were cooled more slowly, and from temperatures of c. $1140-1170^{\circ} \mathrm{C}$. The distinctive thermal history of $12009^{*}$ also characterises impact melted glasses, and impact melted glass spatter is prominent in samples 12017, 12030 and 12054 (LSPET 1970). Impact-melted glasses approaching 12009 and 12040 in composition have been reported (Figure 16, Table VII) as required by our interpretation of 12009 as a fragment of

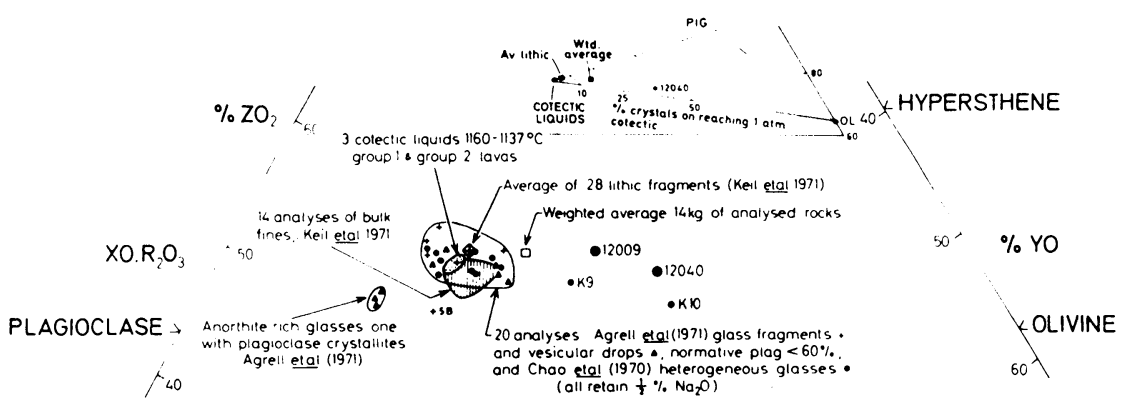

Fig. 16. Projection from diopside into the plane plagioclase-olivine-hypersthene (quartz) (analogous to Figures 6, 12) contrasting Green et al.'s (1971) suggested parental magmas 12009, 12040 with the analysed experimental cotectic liquids (Biggar et al., 1971); the compositions of glass fragments and particles little affected by alkali, or silica depletion, taken to approximate to the average rock composition exposed near the site; and the weighted average composition of $14 \mathrm{~kg}$. of 16 rock samples analysed from this site. The average of 28 lithic basaltic fragments in the soil from this site is also shown.

Two impact melted glass spheres conspicuously poorer in $\mathrm{SiO}_{2}$ or richer in potential ferromagnesian minerals than the majority are indicated, to support the contention that vitrophyres such as 12009 may represent larger globs of impact melted phenocryst-rich target rock.

* The rapid heating and cooling make preservation of pre-existing chemistry, even of alkalis, unremarkable. 
TABLE IX

Details of furnace assembly calibration

$\begin{array}{lllll}\begin{array}{l}\text { Carried out } \\ \text { between } \\ \text { run and run }\end{array} & \begin{array}{l}\text { Calibration } \\ \text { point }\end{array} & \begin{array}{l}\text { Width of } \\ \text { bracket } \\ \text { solid-liquid }{ }^{\circ} \mathrm{C}\end{array} & \begin{array}{l}\text { Date carried } \\ \text { out } \\ 1970 / 1971\end{array} & \begin{array}{l}\text { Correction } \\ \text { applied te } \\ \text { ature from } \\ \text { (a) (b) }\end{array} \\ \text { (initial calibrations) } & \mathrm{Au} & 5.1 & 13 \text { Oct. 19 Oct. }+0.8 \\ 003 \quad 004 & \mathrm{~L}_{2} \mathrm{~S} & 3.2 & 21 \text { Oct. 22 Oct. }-2.1 \\ \text { including } 009 & \mathrm{~L}_{2} \mathrm{~S} & 3.5 & 5 \text { Nov. } 5 \text { Nov. }-1.0 \text { (c) } \\ \text { including } 010 & \mathrm{~L}_{2} \mathrm{~S} & 2.0(\mathrm{~d}) & 25 \text { Nov. } & -1.6 \\ 019 \quad 020 & \mathrm{Au} & \text { Solid (e) } & 26 \text { Nov. } & (+0.8) \\ 020 \quad 021 & \mathrm{~L}_{2} \mathrm{~S} & 2.0(\mathrm{~d}) & 17 \text { Dec. } & -1.5 \\ \text { after } 024 & \mathrm{~L} 2 \mathrm{~S} & \text { Solid (f) } & 24 \mathrm{Dec} . & (-1.5) \\ & \text { Diopside } & 2.7 & 4,5 \mathrm{Feb} . & +1.5\end{array}$

Furnace used for other calibrated work at higher temperatures

initial calibration, then

$\begin{array}{llllll}101 & 102 & \mathrm{~L}_{2} \mathrm{~S} & (\mathrm{~d}) & \text { 22 Apr. 1971 }+3.6 \\ 102 & 103 & \mathrm{Au} & 2.3 & \text { 30 Apr. 1 May }+9.5 \\ 104 & 105 & \mathrm{~L}_{2} \mathrm{~S} & 4.4 & \text { 10 May 11 May }+9.6\end{array}$

used for 106, 107, 108 (glass production) and the replaced by new thermocouple junction.

\begin{tabular}{lllll} 
initial calibrations & $\mathrm{L}_{2} \mathrm{~S}$ & $2.0(\mathrm{~d})$ & \multicolumn{1}{l}{19 May } & +4.0 \\
& $\mathrm{~L}_{2} \mathrm{~S}$ & $(\mathrm{~g})$ & 20 May & \\
then used for 030, 031, $\mathrm{Au}$ & 3.0 & 24 May 25 May & +6.6 \\
$109,110,032,111,033,112$ & & & & \\
$033 \quad 034$ & $\mathrm{~L}_{2} \mathrm{~S}$ & $(\mathrm{~g})$ & June & +4.0
\end{tabular}

(a) These are the corrections applied to the measured e.m.f. to calculate the temperatures quoted by O' Hara et al. (1970), Biggar et al. (1971), and this paper.

(b) A further linear interpolation between $0^{\circ} \mathrm{C}$ at $1064.4^{\circ} \mathrm{C}$ and $4.9^{\circ} \mathrm{C}$ at $1208^{\circ} \mathrm{C}$ must be added to these quoted temperatures to convert them to the International Practical Temperature Scale of 1968. This further correction mainly results from the redetermination of the melting point of lithium metasilicate as $1208^{\circ} \mathrm{C}$ on IPTS 1968 (Biggar, in press).

(c) Based on the wide bracket $\left(3.5^{\circ} \mathrm{C}\right)$. The next line of the table involved a smaller bracket and for greater accuracy the value -1.0 should be replaced by the value between -1.6 (the later and better result) and -2.1 (the value used earlier).

(d) In melting interval known to be less than $2^{\circ}$ (Biggar and O'Hara, 1969).

(e) Thermocouple drift cannot have been greater than $0.8^{\circ}$.

(f) Confirmed solid at $3.1^{\circ}$ below the melting interval result of line 4 . Therefore downward drift of thermocouple emf has not been greater than $3.1^{\circ}$ in fact previous correction of -1.5 continued in use.

(g) Confirmed solid at $2.0^{\circ} \mathrm{C}$ below result of 19 th May.

(h) Control precision is better than $\pm 0.5^{\circ} \mathrm{C}$ (Biggar and O'Hara, 1969); accuracy relative to stated scales is $\pm 2.5^{\circ} \mathrm{C}$. Contrast Green et al. (1971b) who give $\pm 5.0^{\circ} \mathrm{C}, \pm 10^{\circ} \mathrm{C}$ respectively.

impact-melted target material from the phenocryst-enriched base of one of the flows (Figure 14).

(14) Results presented here (Table VIII) and by Biggar et al. (1971) were obtained from close temperature brackets in thermally explored and properly calibrated furnaces 
(Biggar and O' Hara, 1969; and Table IX, Figure 17 this paper), at controlled, known, and calibrated oxygen fugacities (Figure 5; Biggar et al., 1971, Table II), in containers which do not react with the charges (Table X). All temperatures quoted in this and our previous work must be raised $2-5^{\circ} \mathrm{C}$ to correspond with the International Practical Temperature Scale (1968) and our revised melting point for $\mathrm{Li}_{2} \mathrm{SiO}_{3}\left(1208^{\circ} \mathrm{C}\right.$; IPTS, 1968) N.B. The emf of a thermocouple indicates nothing more than the temperature of the thermocouple tip (Figure 17). Sample preparation techniques do not

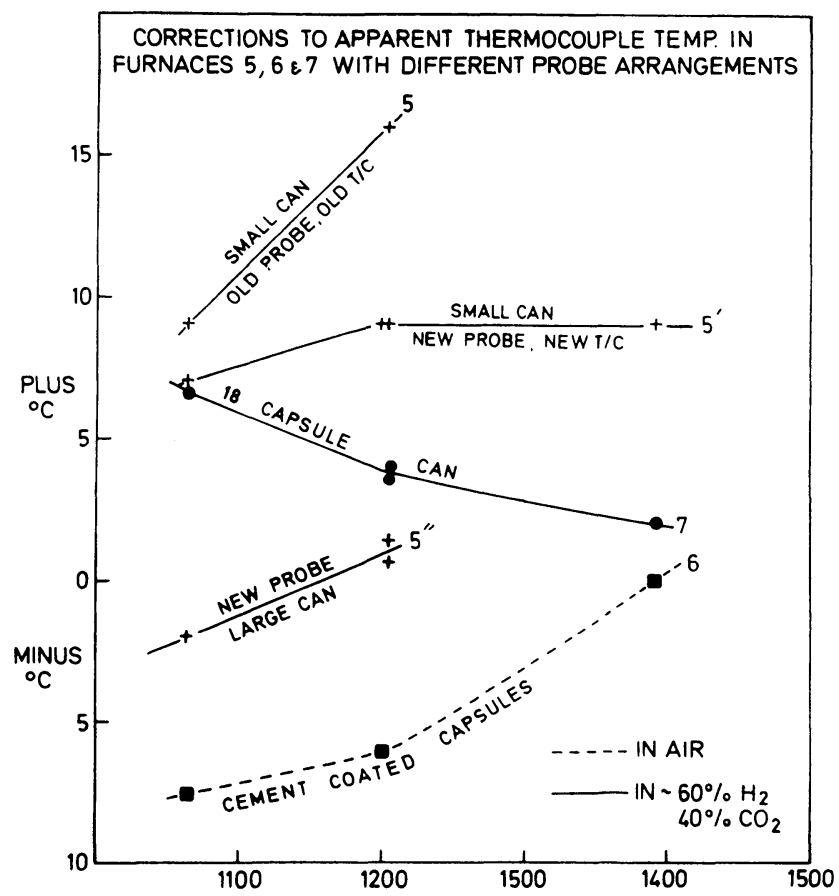

Fig. 17. Plot of corrections to be added to apparent thermocouple temperature as a function of temperature in furnaces of the type used in the studies at Edinburgh.

TABLE X

\begin{tabular}{|c|c|c|c|c|c|c|}
\hline & $\mathrm{SiO}_{2}$ & $\mathrm{TiO}_{2}$ & $\mathrm{Al}_{2} \mathrm{O}_{3}$ & $\mathrm{FeO}$ & $\mathrm{MgO}$ & $\mathrm{CaO}$ \\
\hline 12038 Rock & 47.1 & 3.3 & 13.0 & 17.7 & 6.6 & 11.4 \\
\hline $120381179^{\circ} \mathrm{C}, 5 \mathrm{~h} \quad 0 \%$ crystals & 46.9 & 3.4 & 12.4 & 17.6 & 6.8 & 11.2 \\
\hline $120381160^{\circ} \mathrm{C}, 5 \mathrm{~h}<5 \%$ crystals $^{\mathrm{a}}$ & 46.8 & 3.5 & 12.3 & 17.7 & 6.6 & 11.2 \\
\hline 12064 Rock & 46.4 & 4.1 & 10.5 & 19.9 & 6.4 & 11.7 \\
\hline $120641160^{\circ} \mathrm{C}, 5 \mathrm{~h}<5 \%$ crystals & 46.4 & 4.0 & 10.6 & 19.4 & 6.6 & 11.6 \\
\hline
\end{tabular}

a cotectic liquid, plagioclase, olivine, spinel and two pyroxenes.

Table X, comparing glass analyses from all liquid, or nearly all liquid experiments with bulk rock composition, to illustrate composition control, absence of sampling errors conducive to premature plagioclase crystallization, and absence of iron loss. Data from Biggar et al. (1971) Table V. 
bias the charge compositions, least of all towards excessive potential plagioclase (Table X).

The quenching and microprobe data refer to assemblages of homogeneous equilibrium phases, the apparent variation $(< \pm 2 \%$ Fo in olivine; $< \pm 3 \% \mathrm{Wo}, 2-4 \%$ En in pyroxene; and $\pm 1-4 \%$ major oxides in the glasses, equivalent to \pm c. $1 \%$ olivine in the norm) not greatly exceeding the precision of the method, and arising principally from the difficulty of ensuring that the volume sampled is located exclusively within one phase (c.f. Gibb, 1971) even in the relatively coarse-grained products from rock powder (plate I). No such check could be carried out on the much finer grained products from glass. Total reconstruction of the loaded natural minerals is of course

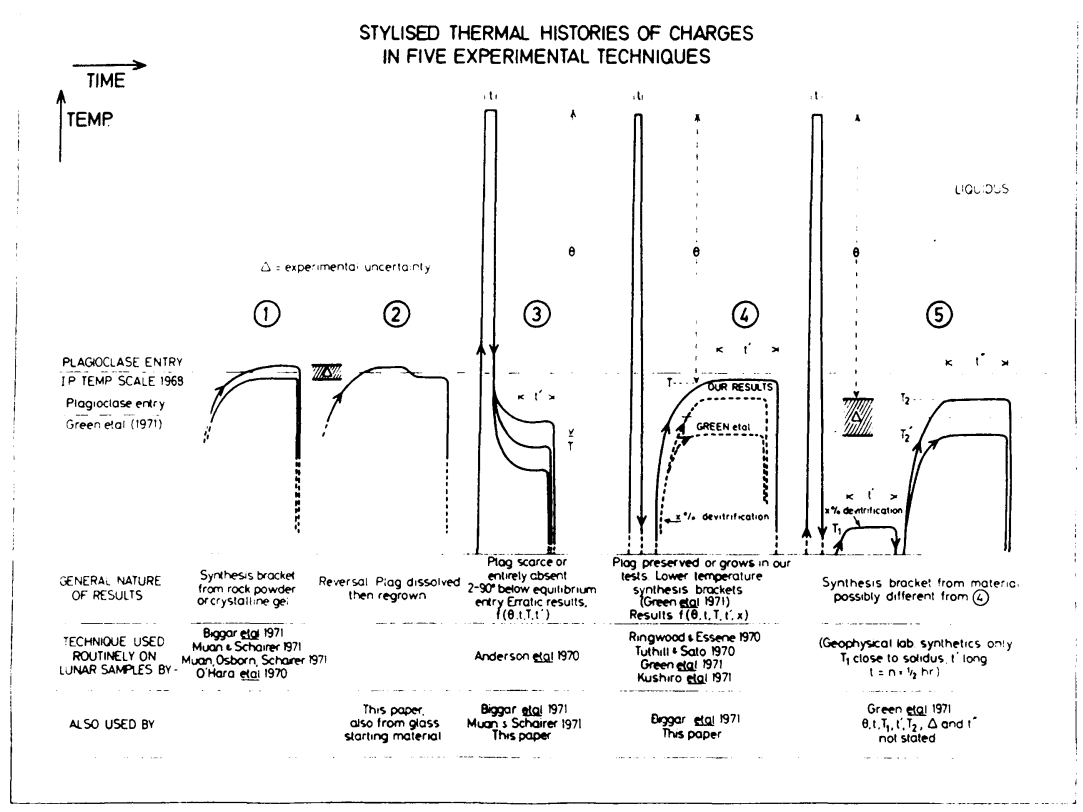

Fig. 18. Diagrammatic representation of thermal sequences used in various experiments.

TABLE XI

Microprobe analysis of cotectic plagioclase-bearing liquids in reversal experiments $1162^{\circ} \mathrm{C} / 1153^{\circ} \mathrm{C}$ showing similarity of results from two starting materials

\begin{tabular}{|c|c|c|c|c|c|c|c|c|c|c|c|}
\hline & $\mathrm{SiO}_{2}$ & $\mathrm{TiO}_{2}$ & $\mathrm{Al}_{2} \mathrm{O}_{3}$ & $\mathrm{Cr}_{2} \mathrm{O}_{3}$ & $\mathrm{FeO}$ & $\mathrm{MnO}$ & $\mathrm{MgO}$ & $\mathrm{CaO}$ & $\mathrm{Na}_{2} \mathrm{O}$ & $\mathrm{K}_{2} \mathrm{O}$ & Total \\
\hline $12038 / 035$ (powder) & 47.27 & 3.49 & 12.12 & 0.25 & 17.35 & & & 11.39 & & 0.13 & 99.24 \\
\hline $12038 / 117$ (glass) & & 3.51 & & 0.19 & & 0.28 & 6.41 & & 0.62 & 0.13 & 99.09 \\
\hline $12040 / 035$ (powder) & 46.53 & 4.64 & 11.33 & 0.19 & 16.94 & 0.22 & 6.95 & 12.11 & 0.46 & 0.13 & 99.50 \\
\hline $12040 / 117$ (glass) $^{\mathrm{a}}$ & 47.21 & 4.06 & 10.46 & 0.28 & 17.17 & 0.25 & 7.94 & 11.42 & 0.33 & 0.13 & 99.25 \\
\hline
\end{tabular}

a Minute crystal size may mean that some pyroxene lay within sample area. 
proved by the reduced $\mathrm{Al}_{2} \mathrm{O}_{3}$ content of the pyroxenes, and the destruction of the zoning.

(15) The only effects likely to arise from the presence of 0.25 bar $\mathrm{H}_{2} \mathrm{O}$ in our furnace atmospheres are accelerated reaction rates, and a slight movement of the total liquid composition towards the primary phase volumes of olivine and pyroxene, which would diminish, not enhance, the appearance of cotectic character.

(16) Thermal sequences used by various workers on Apollo samples or synthetic simulations in different types of experiment are summarised in Figure 18. The entry of plagioclase has been 'reversed'* (Figure 18, sequence 2) in group 2 rocks 12021, 12052,12064 and 12065 between 1144 and $1137^{\circ} \mathrm{C}$ (Table VIII, run 031). Plagioclase has been demonstrated to be present in products of group 1 rocks 12018, 12020, 12038 and 12040 at $1153^{\circ} \mathrm{C}$ (Figure 18 , sequences 1 and 4), irrespective of whether rock powder or largely glass charges were used as starting material (Table VIII, runs 034, $036,113,114$, and 116) or whether the runs lasted $6 \mathrm{~h}$ or $72 \mathrm{~h}$. The appearance of plagioclase in these four rocks has been reversed (Figure 18, sequence 2) between 1162 and $1153^{\circ} \mathrm{C}$ (Table VIII, runs 035,117 ) using rock powder and largely glass starting materials. Microprobe analyses (Table XI) of the residual glasses conform, in each case, to the trend previously established by analyses of liquids developed in $5 \mathrm{~h}$ syntheses (Figure 18, sequence 1) at $1160,1137^{\circ} \mathrm{C}$ (Biggar et al., 1971, Table V). In two of the samples plagioclase entry has been reversed between $1167^{\circ} \mathrm{C}$ and $1156^{\circ} \mathrm{C}$ (Table VIII, runs 032,033 ) but in the other two even this small extent of superheating was sufficient to prevent renucleation of plagioclase.

(17) Charges loaded as glass may devitrify in our furnace atmospheres before arriving at run temperature (Table VIII, runs 109, 110). Experiments loading glass or devitrified glass may, therefore, arrive at temperature as the same phase assemblages and do not necessarily demonstrate even so much as syntheses from contrasted starting materials. Experiments in which liquid is created at high temperature, then lowered to run temperature (Figure 18, sequence 3 ) are particularly prone to delayed or deferred nucleation of plagioclase and pyroxene (Table VIII, section $\mathrm{C}$ ), an effect beautifully displayed in the petrography of 12009 (see Figure 5). It is imperative to limit the superheating used in the first stage of glass preparation for 'reversal' experiments. Other experiments (Table VIII, runs 015, 016, 017) indicate that charges loaded as glass may yield less plagioclase than is obtained from rock powder under the same conditions. The two effects discussed last might be enhanced when dry atmospheres are used.

(18) Nucleation from glass does not always lead immediately, nor even rapidly, to stable phase assemblages (Ostwald, 1897; Volmer, 1939). Products are sensitive to the previous thermal history of the glass (Table VIII, sections B, C). When glasses have been prepared by the several (half-hour) fusions at very high temperature necessary to guarantee homogeneity (Schairer, 1959), and are then used without prior devitrification or annealing, difficulties must be expected. The accumulated experience of the past is worth repeating lest it be altogether overlooked,

* An absolutely valid reversal of an equilibrium involving a phase (e.g. glass) capable of inheriting a metastable internal structural state from the previous thermal treatment is very difficult to devise. 
Nearly all silicate glasses readily undercool. Unless crystals are present in the glass before attempts are made to study phase changes with temperature erratic results and metastable equilibrium may be obtained.... In most silicate systems the determination of the appearance of a crystalline phase at equilibrium practically requires that that phase be present in the starting material. (Schairer 1959).

In glasses which devitrify to olivine, pyroxenes and plagioclase, metastable assemblages may form in minutes and persist for weeks unless devitrification is carried out close to the solidus (O'Hara and Schairer, 1963); these metastable crystals may subsequently enter into metastable crystal-liquid equilibria.

Summarising, then, we consider the assertions and criticisms by Ringwood (1970) and Green et al. (1971) concerning the atmospheric pressure phase equilibria to be unsubstantiated and somewhat authoritarian. We welcome any discussion of atmospheric pressure data on lunar or terrestrial materials which is based on fully reported, quantitative data obtained by well described techniques in calibrated equipment, preferably not relying solely on glass as a starting material.

Sparsely porphyritic rocks like 12038, 12064 are close in composition to low pressure cotectic liquids precipitating plagioclase, spinel, two pyroxenes, and olivine. The plausibility of the choice of these compositions as the parental magmas to local posteruption differentiation at the Apollo 12 site must be judged by the reader in the light of two facts: The average rock exposed to meteorite bombardment resembles the sparsely porphyritic lavas (Figure 16): When erupted these lavas were in that early stage of crystallization which permits the creation of a small proportion of compositions such as 12040,12052 by sinking of the dense crystals through the low viscosity liquid.

Whether vitrophyres, like 12009, with its extreme composition and distinctive thermal history which allies it directly with impact melted materials, can safely be interpreted as anything but impact 'splash' must also be judged by the reader.

Even neglecting the certainty of alkali and other element losses by volatilization during eruption, which must be restored before any lunar lava can be treated as a primary magma, it is our opinion that none of the rocks taken from the Apollo 11 or 12 sites represents even a volatile depleted primary magma from the deep lunar interior; the only identifiable parental magmas bear the stigmata of composition control by low pressure fractional crystallisation.

\section{Summary of Conclusions}

Protohypersthene *-crystallizing basic lavas from the Ocean of Storms were erupted as low pressure cotectic residual liquids from an underlying magma body, already as much as $80-98 \%$ crystallized. The lunar maria are differentiated lava lakes, filled by rock types familiar among the achondrites, floored by early metal precipitates which form mass concentrations, and capped by lava flows representing second-stage extrusion of the late residual liquids of the fractionation sequence. The distinctive geochemical and petrographic characteristics of this magmatic kindred relative to terrestrial ex-

\footnotetext{
* See addendum.
} 
perience were controlled by volatilization losses during eruption and crystallization. The igneous events leading to maria formation may have been very early and triggered by major impacts.

\section{Acknowledgements}

The Natural Environment Research Council (U.K.) supported this research. We thank G. M. Brown, J. E. Dixon, P. L. Roeder and W. C. Storey for their critical reading of this paper.

\section{References}

Agrell, S. O., Long, J. V. P., and Reed, S. J. B.: 1971, 'A comparison of Glasses from the Apollo 11 and 12 Missions' (unpublished).

Anderson, A. T., Crewe, A. V., Goldsmith, J. R., Moore, P. B., Newton, J. C., Olsen, E. J., Smith, J. V., and Wyllie, P. J.: 1970, Science 167, 587.

Biggar, G. M. and O'Hara, M. J.: 1969, Mineral. Mag. 37, 1.

Biggar, G. M., O'Hara, M. J., Peckett, A., and Humphries, D. J.: 1971, Proc. Second Lunar Sci. Conf., Geochim. Cosmochim. Acta Suppl. 2, Vol. 1, 617.

Brown, G. M., Emeleus, C. H., Holland, J. G., Peckett, A., and Phillips, R.: 1971, Proc. Second Lunar Sci. Conf. Geochim. Cosmochim. Acta Suppl. 2, Vol. 1, 583.

Brown, G. M. and Peckett, A.: 1971, Nature 234, 262.

Chapman, D. R. and Scheiber, L. C.: 1969, J. Geophys. Res. 74, 6737.

Chao, E. C. T., Boreman, J. A., Minkin, J. A., James, O.B., and Desborough, G. A.: 1970, J. Geophys. Res. 75, 7445.

Clarke, D. B.: 1970, Contrib. Mineral. Petrol. 25, 203.

Compston, W., Chappell, B. W., Arriens, P. A., and Vernon, M. J.: 1970, Proc. Apollo 11 Lunar Sci. Conf., Geochim. Cosmochim. Acta Suppl. 1, Vol. 2, 1007.

Compston, W., Berry, H., Vernon, M. J., Chappell, B. W., and Kaye, M. J.: 1971, Proc. Second Lunar Sci. Conf., Geochim. Cosmochim. Acta Suppl. 2, Vol. 2, 1471.

De Maria, G., Balducci, G., Guido, M., and Piacente, V.: 1971, 'Mass Spectrometric Investigation of the Vaporization Process of Lunar Samples', Second Lunar Sci. Conf., Geochim. Cosmochim. Acta Suppl. 2, Vol. 2, 1367.

Duke, M. B. and Silver, L. T.: 1967, Geochim. Cosmochim. Acta 31, 1637.

Essene, E. J., Ringwood, A. E., and Ware, N. G.: 1970, Proc. Apollo 11 Lunar Sci. Conf., Geochim. Cosmochim. Acta Suppl. 1, Vol. 1, 385.

Gibb, F.: 1971, Contr. Mineral. Petrol. 30, 103.

Green, D. H., Ringwood, A. E., Ware, N. G., Hibberson, W. O., Major, A., and Kiss, E.: 1971a, Proc. Second Lunar Sci. Conf., Geochim. Cosmochim. Acta Suppl. 2, Vol. 1, 601.

Green, D. H., Ware, N. G., Hibberson, W. O., and Major, A.: 1971b, Earth Planetary Sci. Letters 13,85 .

Haggerty, S. E. and Meyer, H. A. O.: 1970, Earth Planetary Sci. Letters 9, 379.

Hytonen, K. and Schairer, J. F.: 1961, Yearb. Carnegie Inst. Wash. 60, 125.

James, O. B. and Jackson, E. D.: 1970, J. Geophys. Res. 75, 5793.

Jamieson, B. G.: 1970, Mineral. Mag. 37, 537.

Keil, K., Prinz, M., and Bunch, T. E.: 1971, Proc. Second Lunar Sci. Conf., Geochim. Cosmochim. Acta Suppl. 2, Vol. 1, 319.

Kushiro, I. and Haramura, H.: 1971, Science 171, 1235.

Kushiro, I. and Nakamura, Y.: 1970, Proc. Apollo 11 Lunar Sci. Conf. Geochim. Cosmochim. Acta Suppl. 1, Vol. 1, 607.

Kushiro, I., Nakamura, Y., Kitayama, K., and Akimoto, S.: 1971, Proc. Second Lunar Sci. Conf., Geochim. Cosmochim. Acta Suppl. 2, Vol. 1, 481.

LSPET (Lunar Sample Preliminary Examination Team): 1970, Apollo 12 Preliminary Science Report, NASA, Washington, D.C.

LSPET (Lunar Sample Preliminary Examination Team): 1971, Apollo 14 Preliminary Science Report, NASA, Washington, D.C. 
Marvin, U. B., Reid, J. B. Jr., Taylor, G. J., and Wood, J. A.: 1972, Abstracts 3rd Lunar Sci. Conf., NASA Houston.

Muan, A., Hauck, J., Osborn, E. F., and Schairer, J. F.: 1971, Proc. Second Lunar Sci. Conf., Geochim. Cosmochim. Acta Suppl. 2, Vol. 1, 497.

Muan, A. and Schairer, J. F.: 1971, Yearb. Carnegie Inst. Wash. 69, 243.

O’ Hara, M. J.: 1961, Mineral. Mag. 32, 848.

O'Hara, M. J.: 1963, Amer. J. Sci. 261, 32.

O'Hara, M. J.: 1968, Earth Sci. Rev. 4, 69.

O'Hara, M. J., Biggar, G. M., Richardson, S. W., Jamieson, B. G., and Ford, C. E.: 1970, Proc. Apollo 11 Lunar Sci. Conf., Geochim. Cosmochim. Acta Suppl. 1, Vol. 1, 695.

O’Hara, M. J., Biggar, G. M., Richardson, S. W., Ford, C. E., and Jamieson, B. G.: 1971, Phys. Earth Planetary Int. 4, 181.

O’Hara, M. J. and Schairer, J. F.: 1963, Yearb. Carnegie Inst. Wash. 62, 107.

Osborn, E. F. and Tait, D. B.: 1952, Amer. J. Sci. 250 A (Bowen vol.) 413.

Ostwald, W.: 1897, Z. Phys. Chem. 22, 289.

Prinz, M., Bunch, T. E., and Keil, K.: 1971, Contrib. Mineral. Petrol. 32, 211.

Ringwood, A. E.: 1970, J. Geophys. Res. 75, 6453.

Ringwood, A. E. and Essene, E.: 1970, Proc. Apollo 11 Lunar Sci. Conf., Geochim. Cosmochim. Acta Suppl. 1, Vol. 1, 769.

Ringwood, A. E. and Green, D. H.: 1972, 'Crystallization of Plagioclase in Lunar Basalts and Its Significance' (in press).

Roedder, E. and Weiblen, P. W.: 1970, Proc. Apollo 11 Lunar Sci. Conf., Geochim. Cosmochim. Acta Suppl. 1, Vol. 1, 801.

Roeder, P. L. and Emslie, R. F.: 1971, Contr. Mineral. Petrol. 29, 275.

Roeder, P. L. and Osborn, E. F.: 1966, Amer. J. Sci. 264, 428.

Schairer, J. F.: 1959, in J. O'M. Bockris, J. L. White, and J. D. Mackenzie (eds.), Physico-Chemical Measurements at High Temperatures, Butterworths, 117.

Scoon, J.: 1971, Proc. Second Lunar Sci. Conf., Geochim. Cosmochim. Acta Suppl. 2, Vol. 2, 1259.

Strom, R. G.: 1971, Mod. Geol. $2,133$.

Tuthill, R. L. and Sato, M.: 1970, Geochim. Cosmochim. Acta 34, 1293.

Urey, H. C., Marti, K., Mei-Kao, L., and Hawkins, J. W.: 1971, Proc. Second Lunar Sci. Conf., Geochim. Cosmochim. Acta Suppl. 2, Vol. 2, 987.

Volmer, M.: 1939, Kinetik der Phasenbildung, Steinkopff, Dresden.

Wager, L. R. and Brown, G. M.: 1968, Layered Igneous Rocks, Oliver and Boyd, Edinburgh.

Wasserburg, G. J. and Papanastassiou, D. A.: 1971, Earth Planetary Sci. Letters 13, 97.

Weill, D. F., McCallum, I. S., Bottinga, Y., Drake, M. J., and McKay, G. A.: 1970, Proc. Apollo 11

Lunar Sci. Conf., Geochim. Cosmochim. Acta Suppl. 1, Vol. 1, 937.

Addendum. Green et al. (1971b) doubt our finding of protohypersthene on the strength of their experiments carried out under appreciably different conditions. The facts to bear in mind are: (i) Biggar et al. (1971) analysed inverted protohypersthene from $12040\left(\mathrm{Ca}_{7} \mathrm{Mg}_{67} \mathrm{Fe}_{26}\right)$ and observed inverted orthorhombic phase present in the range $1160-1200^{\circ} \mathrm{C}$, and $1135-1160^{\circ} \mathrm{C}$ in 12021 . Eruption temperatures lay within these ranges, hence inverted protohypersthene is to be expected in the rocks, all other factors being equal. (ii) Ross et al. (1971, Abstract, 2nd Lunar Science Conf.) reported inversion of calcium-poor pigeonite cores $\left(\mathrm{Ca}_{9} \mathrm{Mg}_{63} \mathrm{Fe}_{28}\right)$ from 12021 to orthorhombic structures (? space group) at $1160-1215^{\circ} \mathrm{C}$, in their heating experiments. (iii) Hollister et al. (1971, Proc. 2nd Lunar Sci. Conf., p. 529-557) report orthorhombic cores in pigeonite from 12065. Aspects of their analysis 9-1-6 $\left(\mathrm{Ca}_{6} \mathrm{Mg}_{66} \mathrm{Fe}_{28}\right)$ are compared with our inverted protohypersthene (12040/4) $\mathrm{TiO}_{2} 0.43,0.43 ; \mathrm{Al}_{2} \mathrm{O}_{3}$ 1.01, 1.08; $\mathrm{Cr}_{2} \mathrm{O}_{3}$ 0.77, 0.46 (misprint in earlier text); $\mathrm{CaO} 2.90,3.39 ; \mathrm{FeO} 17.96,16.72 ; \mathrm{MgO} 23.50$, 23.81. (iv) Brown et al. (1971), Gay et al. (1971, Proc. 2nd Lunar Sci. Conf., p. 377-392) suggest that curving cracks in pigeonite phenocryst cores of 12040,12065 may reflect the $\mathrm{C} 2 / c \rightarrow \mathrm{P} 2{ }_{1} / c$ inversion in pigeonite; Ross et al. (1971) did not report C2/c structure formation but Prewitt et al. (1971, Proc. 2nd Lunar Sci. Conf., p. 59) did for material of this general composition at $1000^{\circ} \mathrm{C}$. A few cracks are present in the larger prisms of pigeonite in our runs, and the $\mathrm{C} 2 / c \rightarrow \mathrm{P} 21 / c$ inversion may also have occurred. Gay et al. (1971) comment on unusual pyroxene trends in 12065, matched by a terrestrial 
protohypersthene precipitating rock. (v) Yoder, Tilley and Schairer (1964, Yearb. Carnegie Instn. Wash. 63, 121-129) reported an orthorhombic calcium-poor pyroxene stable at these relevant compositions and temperatures, identified as protohypersthene by the same authors (1963, Yearb. Carnegie Instn. Wash. 62, 84-95) with detailed discussion (1963, p. 90). (vi) Low-calcium-pyroxene cores comparable with Biggar et al.'s (1971) analysed protohypersthene form a smaller part of the rock powder as loaded, than do the large crystals with curving cracks which we interpret as inverted protohypersthene. Furthermore, had our protohypersthene been undissolved residual phenocryst cores it should have been more abundant in, not absent from, the lower temperature experiments. (vii) Finally we refer to results in Table VIII, run 006 which seem to eliminate worries about unmelted residual material. 